\title{
Violence Against Women
}

\section{Hidden voices: Disabled Women's Experiences of Violence and Support over the lifecourse}

\begin{tabular}{|r|l|}
\hline Journal: & Violence Against Women \\
\hline Manuscript ID: & VAW-14-04-0015 \\
\hline Manuscript Type: & Research Article \\
\hline Keywords: & Disabled women, violence, support, lifecourse, barriers \\
\hline \multicolumn{2}{|}{} \\
\hline
\end{tabular}

SCHOLARONE ${ }^{\mathrm{m}}$

Manuscripts 
Hidden voices: Disabled Women's Experiences of Violence and Support over the Lifecourse

Dr Sonali Shah,

Strathclyde Centre for Disability Research, School of Social and Political Sciences, Glasgow University

Dr Sarah Woodin

School of Sociology and Social Policy, University of Leeds

Dr Lito Tsitsou

School of Social and Political Sciences, Glasgow University

\begin{abstract}
Violence against women is a worldwide social and human rights problem that cuts across cultural, geographical, religious, social and economic boundaries. It affects women in countries around the world, regardless of class, religion, disability, age or sexual identity. International evidence shows that approximately every 3 to 5 women experienced physical and/or sexual violence by an intimate partner. However, across the globe, women and girls with impairments or life-limiting illnesses are more susceptible to different forms of violence across a range of environments and by different perpetrators including professionals and family members as well as partners. However they are likely to be seriously disadvantaged in gaining information and support to escape the abusive relationships. This paper stems from the UK part of an ongoing four country comparative study (2013-15) funded by the European Commission. It presents preliminary findings, generated from life history interviews, about disabled women's experiences of violence and access to support (both formal and informal) over their lifecourse, and their aspirations for the prevention of violence in the future. The paper includes examples of impairment-specific violence not experienced by non-disabled women. By bringing the voices of disabled women into the public domain, the paper will facilitate a historically marginalised group to contribute to the debate about disability, violence and support.
\end{abstract}

\title{
Introduction
}


Internationally and nationally, violence against women has been recognized as one of the most serious forms of gender-based violations of human rights. Estimations from the Council of Europe suggests that between one fifth to one quarter of women across countries in Europe experience domestic violence at some point during their lifetime. Historically, violence against women has been conceived as a manifestation of the unequal power relations between men and women which has led to the discrimination and oppression of women, and their subordination in relation to men. Women and girls are exposed to different forms of violence over their lifecourse. This includes domestic violence, rape, sexual harassment, forced marriage, 'honor' killings and genital mutilation. Such violations of females have been recognized as a worldwide social and human rights problem that cuts across cultural, geographical, religious, social and economic boundaries affecting women in countries around the world, regardless of class, religion, disability, age or sexual identity. According to the United Nations, violence against women and girls is defined as:

"any act of gender based violence that results in, or is likely to result in, physical, sexual or mental harm or suffering to women, including threats of such acts, coercion or arbitrary deprivation of liberty, whether occurring in public or in private life."

In the U.K. the concept of domestic violence is informed by Women's Aid, a national charity working to end violence against women in the U.K. With a network of 350 domestic and sexual violence services across the U.K., Women's Aid defines domestic violence as: "physical, psychological, sexual and financial violence that takes place within an intimate or family-type relationship and forms a pattern of coercive and controlling behavior. This could include forced marriage and so-called 'honor' crimes. Domestic violence often includes a range of abusive behaviors, not all of which are inherently violent."

(Women's Aid, 2007)

However, many authors have noted that dominant definitions of violence focus on the experiences of violence by non-disabled women, but fail to represent those of disabled women even though there is a plethora of evidence to suggest that disabled women and girls are more susceptible to systemic and individual violence across their lifecourse compared to their able-bodied counterparts (Schröttle and Glammeier, 2013; Thiara et al, 2011). Studies 
conducted in Europe, North America and Australia have shown that over half of all disabled women have experienced physical abuse, compared with one third of non-disabled women (UN, 2006). Nearly $80 \%$ of disabled women have been victims of psychological and physical violence, and are at a greater risk of sexual abuse than non-disabled women (European Parliament, 2006). Balderston (2014) suggests that in the United Kingdom, disabled women are two to five times more likely than men and non-disabled women to experience sexual violence $^{1}$. Further, several studies report that disabled children are approximately three times as likely to be sexually abused than non-disabled children (Sullivan and Knutson, 2000). Accounting for gender, Sobsey et al (1997) found that significantly more disabled girls than disabled boys were likely to experience sexual abuse. This supports the work of Kelly et al in 1991 which suggested that one in four disabled boys and one in two disabled girls experience some form of sexual abuse before their eighteenth birthday.

This high proportion of disabled women exposed to and experiencing violence over their lives could be associated with a number of factors, including the fact they are perceived as dependent asexual beings who cannot achieve the goals of womanhood - of engaging in healthy sexual or romantic relationships and of fulfilling traditional gender roles of wife and mother (Bagum, 1992). Thiara et al (2012) suggest that the perception that disabled females are not 'proper' sexual beings women could lead to them being at greater risk of sexual abuse. Further, Cockram (2003) suggests that the fact disabled women and girls have to depend on others for basic personal and social needs places them at greater risk of abuse compared to non-disabled women. This is evidenced by Barron (2010) who cites the experience of a young disabled woman being offered assistance to the toilet by a male. She contends that while this could be interpreted as the woman being viewed as asexual, it could equally be seen as a way for a potential perpetrator to exploit the dependent nature of the relationship and be intimate with the disabled women who they, in fact, do view as a sexual being.

The objectification of disabled women's bodies across their life course has also been suggested as creating opportunities for the abuse of disabled women. Work by Bagum (1992) suggests that there is a tendency for society to reduce disabled women's bodies to asexual objects which can be controlled and manipulated by others. This is concurred by 
Belsky (1980) who suggest contributing factors include the cultural devaluation of women and disabled people. Womendez and Schneiderman (1991) point out another significant factor as the lack of opportunities disabled women are given to learn the differences between appropriate and inappropriate sexual behaviour. Other authors point out how disabled girls have had limited exposure to sexual knowledge and opportunities while growing up due to being excluded from the cultural spaces where these exchanges take place, or being constrained by high levels of surveillance (Nosek et al, 2001; Shakespeare et al, 1996; Shakespeare, 2014). This opens up ample opportunities for the abuse of disabled females within institutional practices as well as from different individuals who they interact with over their lives. These include professionals, paid carers, family members and intimate partners. For instance, Campling (1981:10) pointed out how her body was manipulated by health professionals when she was young:

'as the doctors poked and studied me endlessly I learnt more quickly then some non-disabled women that I'm seen as an object...'

This is similarly evidenced by Thomas' (1999) who presents the narratives of disabled women with different experiences of gender and disability. One of the women's recollection of being routinely exposed to sexual abuse by a male doctor who knew she had no feeling in her lower body, in the name of 'routine check-up', exemplifies the simultaneous oppression resulting from the interplay of disablism and sexism.

Professional, social and institutional practices, as discussed above, have often been taken for granted as a normal part of disabled people's everyday lives, and not considered to be 'abusive practices' in the same way that they would if experienced by a non-disabled child/adult. Work by Westcott and Cross (1996), and Shah and Priestley (2011) draw attention to practices of public stripping, disabled children parading naked in front of medical professional and students who are strangers to them, and medical photography of disabled children and young people, experiences which would not be suffered by non-disabled children. These differing notions of acceptable and abusive behaviour for disabled and nondisabled individuals is reflected in a quote by a Social Services Team Leader in a study by the British Association for the Study and Prevention of Child Abuse and Neglect (1992) (cited in Morris, 1996:117) 
We accept that physical means of control are more acceptable for children with learning disabilities than for other children. Children are locked in their bedrooms at night. I know a child who is tied to a chair to keep him safe. We accept the differences but should we?

Such attitudes by practitioners create barriers to knowledge, disclosure and reporting in relation to the abuse of disabled children. Kennedy (1996) argues that there is a notion, among professionals, that abuse experienced by disabled children is of less significance than that experienced by non-disabled children. This in itself becomes a barrier to accessing support and protection. For instance, although disabled and non-disabled children are equally manipulated by the perpetrator to blame themselves, the former are less likely to be believed when disclosing the act (Higgins and Swain, 2010). Even when signs of abuse, including sexual abuse, is recognised practitioners seem to associate it with the child's impairment (Kennedy, 1996).

Although disabled women and girls experience the same types of abuse as their non-disabled contemporaries, they are likely to be subjected to additional types of abuse specific to being disabled. The impairment-specific acts of abuse include those which simultaneously increase the powerfulness of the perpetrators and the powerlessness of the disabled women. Curry et al (2001) highlight experiences such as the misuse of medication, isolating individuals from family and friends, removing the battery from the woman's power wheelchair as forms of abuse that non-disabled women/ girls do not experience. However, as previously mentioned, these practices/ actions may not be seen as abuse, either by professionals or by disabled people themselves. Even when disabled people do feel they are victimized, very few are in a position to report it to the authorities or a women's service such as Women's Aid. Several authors suggest a number of reasons for this, connected to the fact that disabled women and girls are likely to experience additional abuse by people on whom they are reliant, be they family members and paid carers, as well as intimate partners. Sobsey and Doe (1991) report how disabled women are likely to experience additional abuse at the hands of people who are supposed to "care" for them, such as personal assistants, parents, health care workers and staff of residential settings (i.e. schools or care homes). The dependent status of the disabled woman in such situations reinforces the notion that they are incompetent and powerless to resist or report perpetrators' advances, making them more likely to be victimized than nondisabled women (Nosek, et al 2001). This is supported by Saxton et al (2001) who found that disabled women are less likely get support or prevented from accessing other sources of support when they are reliant on their abuser. At the same time, in cases where the perpetrator 
is also the disabled girl's/ woman's assistant they may be particularly reluctant to make a charge for fear they would be left with no-one to provide the personal care they require to live independently (Martin et al, 2006; Kennedy, 1996).

Apart from the barriers caused by perpetrators, much evidence suggests disabled women face several obstacles when seeking professional support which is open to non-disabled women (Thiara et al, 2012). Such includes the lack of physical access to services, the inaccessibility of publicity materials, lack of accessible alternative accommodation such as refuges, and as suggested above, social stereotypes that assume disabled women to be asexual, tragic or burdens to society. Further, professional's poor understanding of disability and impairmentspecific abuse shape responses to disabled women and frequently leave them without protection from more general sources of support, such as the criminal justice system or other legal structures. For instance, disabled women may experience disbelief when approaching service providers about experiences of abuse in relation to their impairment, or even may avoid accessing formal support for fear they would not be believed over the non-disabled perpetrator. Further where children are involved, disabled mothers experiencing violence may not seek professional help for fear they could be perceived as incompetent parents and experience interventions by legal and medical professionals in their reproductive lives (Booth and Booth, 1994; Priestley, 2003). Bashall and Ellis (2013) note how policy makers and society in general do not conceive the impairment-specific acts of abuse as domestic violence or hate crime, but more as "some innate vulnerability caused by their impairment" (p.116). This in itself is a major barrier to prevention and to accessing services and support. Therefore, despite the recognised large numbers of disabled women encountering violence, the obstacles they face, including the legal and protection frameworks that exist to protect women from violence, prevent them from getting the support they deserve to end the abuse in the lives.

So it is clear that continuation of violence of disabled women often stems from the inequalities associated with being disabled and female in a patriarchal society constructed around the non-disabled majority. The intersectionality of disablism and sexism helps to materially locate disabled women on the axis of power and disadvantage, and therefore provides a tool for understanding to complexity of disabled women's experiences of abuse and disadvantage. As Jennings (2003) pointed out: 
Women and girls with disabilities live at the intersection of gender and disability bias. As a consequence, they experience higher rates of violence and lower rates of service provision than their non-disabled peers.

However, the historic marginalisation of disabled women, by disablism and patriarchy, means that regardless of the high rates of victimization experienced by disabled women (as suggested by the research reviewed above), their experiences and voices remain absent from policy and research agendas, both in areas of domestic violence and disability. This 'invisibility' from these two camps has, in turn, contributed negatively to the high victimization of disabled women (Cockram, 2003; Thiara et al, 2012). Through the presentation of some preliminary qualitative evidence generated from the U.K. part of an EU funded four country comparative study, the aim of this paper is to examine disabled women's experiences of violence and access to support (both formal and informal) over their lifecourse. In this work, disabled women are identified according to the definition outlined by the United Nations Convention on the Rights of Persons with Disabilities (2006):

Women with disabilities include those who have long-term physical, mental, intellectual or sensory impairments which in interaction with various barriers may hinder their full and effective participation in society on an equal basis with others

Through the first-hand accounts of disabled women, this paper will present examples of how women experienced different types of violence including impairment-specific violence. It will highlight the main barriers and enablers to accessing specialist and more general victim support services at different points in the life course. It will also bring forth disabled women's aspirations for the protection of survivors of violence and the prevention of violence against disabled women in the future. In so doing, it will provide the voices of a simultaneously oppressed group with the opportunity to enter the public domain and inform macro-level decisions that impact their lives. Before presenting this data, the paper will briefly discuss the legal instruments, both international and U.K. based, which currently exist in relation to violence against women in general and disabled women in particular.

\section{Law and Policy}


Acts of violence, once seen as a more private matter, have prompted the development of various international and national legal human rights instruments to protect women and girls from harm and abuse. With over three million women affected by a different acts of violence and abuse the UK government has signed up to main international treaties related to violence against women and on the rights of disabled people. National legal instruments have also been developed in the relation to violence against women and disabled people in the U.K. However, a policy review conducted as part of the first phase of the EU research study mentioned above revealed noticable gaps in existing legislation in relation to disabled women. This section will briefly discuss some of the international and national legal instruments relevant to violence for women in general and for disabled women in particular. It is by no means an exhaustive list.

In 1989 the Convention on the Rights of a Child was the first international treaty proposed to protect the rights of children under age 18. With 54 articles it sought to cover a range of human rights including the protection from violence (Article 19). The UN also developed other instruments in relation to protection and prevention of violence against women. UK government signed the Convention on the Elimination of All Forms of Discrimination against Women (CEDAW) on 22 July 1981 and ratified it on the 7 April 1986. Further to this the UK acceded the CEDAW Optional Protocol (OP) on the 17 December 2004 and it entered into force on 17 March 2005. The Ministry of Justice ${ }^{2}$ has responsibility for its implementation in the UK. The Treaty has had symbolic importance in influencing the development of other laws and policies in the UK as well as allowing the government to be held to account through the relevant provisions of General Recommendations 19, 14 and 24. A number of reservations remain in place, for Articles 9, 11, 15 and 16. In 2002 The Adoption and Children Act amended the 1989 Children Act, amending the definition of 'significant harm' to reflect the impact of domestic abuse on children. In December 2003 the Protocol to Prevent, Suppress and Punish Trafficking in Persons, especially Women and Children entered into force. It supplemented United Nations Convention Against Transnational Organised Crime. The protocol states to prevent and combat trafficking in persons, and protects victims of trafficking. The prevention and protection of trafficked persons includes women and children who are trafficked for commercial sexual exploitation. The protocol was acceded by Council of Europe that opened

\footnotetext{
${ }^{2}$ Ministry of Justice http://www.justice.gov.uk/ [26.3.13]
} 
a Council of Europe Convention on Human Trafficking signed by U.K. in 2005. Although complementary protection is ensured through the Lanzarote Convention on the Protection of Children against Sexual Exploitation and Sexual Abuse (2007), the thirty signatories does not include the U.K. as yet.

As well as law and policy with respect to women in general, there is also law and policy in relation to disabled people which seeks to protect the rights of disabled people, with articles specific to disabled women. The UN Convention on the Rights of People with Disabilities $(\mathrm{UNCRPD})^{3}$, is the first international treaty to promote the civil rights of disabled people in all aspects of social life. Articles 6, 15,16 and 17 are particularly relevant to this topic. In Article 6, the UNCRPD recognises that disabled girls and women encounter multiple discrimination and propose to take measures to ensure they can enjoy their human rights. Article 15 proposes to take legislative and other measures to prevent disabled people from being subjected to torture or cruel degrading treatment. Article 16 is specific to ensuring disabled people are free from violence, exploitation and abuse. Article 17 offers mechanisms to ensure disabled women can retain their mental and physical dignity.

Legal remedies are available in the UK through both civil law, which aims at protection for women experiencing violence, and criminal law, which aims at punishment of the offender. These include the Family Law Act 1996, Homelessness Act 2002 and Housing Act 1996. In 2004, Domestic Violence, Crime and Victims Act came into force to amend Part 4 of the Family Law Act 1996, the Protection from Harassment Act 1997 and the Protection from Harassment (Northern Ireland) Order 1997. It makes many acts of violence arrestable offences including public order offences, assault and battery, threats to kill, harassment, sexual offences, kidnap and child cruelty. Under criminal law, the Protection from Harassment Act 1997 allows a woman who has experienced violence to take out a restraining order that bars the perpetrator from making contact with the survivor. This law aimed at dealing with the problem of stalking, although Women's Aid reports that follow up research revealed $40 \%$ of the worst offences involved harassment by ex-partners. ${ }^{4}$ In 2012 this Act was updated by the Protection of Freedoms Act 2012, which made two new offences of

\footnotetext{
${ }^{3}$ First international treaty to afford disabled people full human rights: http://www.un.org/disabilities/convention/conventionfull.shtml

${ }^{4}$ Women's Aid Protection under Criminal Law (2008) http://www.womensaid.org.uk/domestic-violencearticles. asp? itemid=1401\&item Title=Protection+under+criminal+law\&section=00010001002200070001\&sectionTi tle=Articles $\% 3 \mathrm{~A}+$ criminal+law\#harrass [4.4.13]
} 
stalking and stalking involving fear of violence or serious alarm and distress, also allowing for the police to search premises in relation to these crimes. The Forced Marriage (Civil Protection) Act 2007 protects individuals from being forced into marriage without their free or full consent. It came into force in England and Wales on the 25 November 2008, also covering Northern Ireland, and the Forced Marriage (Protection and Jurisdiction) (Scotland) Act 2011, was passed by the Scottish Parliament on 22 March 2011. Under the provisions of the legislation, a Forced Marriage Protection Order may be issued, prohibiting that a person be taken overseas or ensuring that they are returned to this country. So, although the act of forced marriage itself is a civil offence, it has consequences that are considered which are deemed criminal under other legislation, including the Sexual Offences Act 2003 or Domestic Violence, Crime and Victims Act 2004.

In terms of legislation specific to disabled women, the Equality Act 2010 amalgamated various laws, including those relevant to disabled people and women. The Disability Discrimination Act 1995 (DDA) set out the first foundations of civil rights legislation for disabled people. According to the Act it is unlawful for any person to subject a disabled person to harassment which has the purpose/effect of violating the disabled person's dignity, or creating a hostile, offensive, humiliating or degrading environment. This is detailed, in Part I of the Act, in accordance to public authorities, including employers, advocates and barristers. DDA 2005 amends DDA 1995. It applies to access to goods and services, including legal services. Individuals with cancer, HIV and mental health difficulties are also covered by the DDA. Further it applies to private clubs as well as public services. Enforcement of accessibility legislation and standards are clearly particularly important in relation to access to specialised services. It may be noted however that charities are exempt from some of the requirements for building accessibility under sections 193 and $194^{5}$. This may include some charities that operate to support women who have experienced violence.

Although the laws and policies, highlighted above, were not explicitly mentioned in the women's survival stories, in some instances they did, albeit indirectly, contribute to their escape and subsequent protection.

\section{Methods}

${ }^{5}$ Equality Act 2010 Section 193 http://www.legislation.gov.uk/ukpga/2010/15/section/193 [17.4.13] 
The aforementioned EU funded research project on which this paper is based adopted a mixed method approach to cover four phases of empirical fieldwork. These phases included an online survey of specialist violence support services across the U.K., semi-structured interviews with key 'experts' (representatives from 15 of the services included in the survey), four focus group discussions with a range of disabled women in different parts of the U.K., and life story interviews with 15 disabled women.

This paper will report on preliminary data from the final phase of empirical fieldwork. It adopted a life story approach to generate data about the social world of a sample of disabled women across the U.K. who are survivors of violence and have experience of specialist support services. According to Atkinson (1998: 8), a life story

is the story a person chooses to tell about the life he or she has lived, told as completely or as honesty as possible. What is remembered of it, and what the teller wants to know of it, usually as a result of a guided interview by another.

The method of life history interviews to learn about experiences of disabled people, and especially disabled women, is still a relatively new approach (French and Swain, 2006; Shah and Priestley, 2011). It is not only a personal narrative, but offers a unique understanding of development across time (both biographical and historical) and space. As argued by Bertaux (1981) when a life story is told, we not only hear the personal narrative, but also become aware of the interplay between the individual and the broader social structures that gives substance to the narrative and contextualizes it within time and space. Further, life stories offer a mechanism to learn about the experiences of perhaps oppressed or ignored groups (such as disabled girls and women who have survived violence) not ordinarily included in official documentation. In so doing it provides new understandings to existing knowledge on disability and on violence against women/girls, which can challenge assumptions and help to re-examine official documentation about the subject (French and Swain 2006). It also allows a historically marginalised group (disabled women) to become agents of their knowing or knowledge creators.

The life story approach also favours a social model lens and allows a space for nonmedicalised narratives to be voiced by disabled women, providing a space where participants can control when and how they communicate. It allows for the focus to move beyond the 'life experiences of disabled people' and towards the 'experiences of disability in people's lives', 
responding to Finkelstein's reminder that 'disabled people are not the subject matter of social interpretation of disability' (Finkelstein, 2001: 1). Thus, the primary purpose is to reveal and challenge the network of social relations, institutions and barriers that inhibit the full participation and equality of disabled women when trying to access support for abuse.

\section{Sample and Recruitment}

The target sample included disabled women within age range 18-65, stipulated in the original proposal for reasons relating to ethics and funding. All participants identified themselves as being survivors of violence, and had experiences of accessing support at different points in their lives. The sampled used for illustration in this paper are drawn from six case studies, a sub-set from the larger study. The names have been altered using pseudonyms chosen by the participants. The characteristics of the sub-sample such as their age, ethnic origin, marital status and impairment type are summarized in the table 1 below:

\begin{tabular}{|l|l|l|l|l|l|}
\hline $\begin{array}{l}\text { PSEUDO } \\
\text {-NAME }\end{array}$ & AGE & IMPAIRMENT & $\begin{array}{l}\text { REGION, } \\
\text { COUNTRY }\end{array}$ & $\begin{array}{l}\text { MARITAL } \\
\text { STATUS }\end{array}$ & CHILDREN \\
\hline Barb & 47 & Visual Impairment & Scotland & Divorced & yes \\
\hline $\begin{array}{l}\text { Lois } \\
\text { Eldritch }\end{array}$ & 22 & Mobility/Degenerative & England & $\begin{array}{l}\text { In } \\
\text { relationship }\end{array}$ & no \\
\hline Alison & 47 & Mobility & Scotland & $\begin{array}{l}\text { Divorced } \\
\text { and in } \\
\text { relationship }\end{array}$ & yes \\
\hline Adel & 34 & Mobility & England & Single & no \\
\hline Samantha & 48 & Mobility & England & Married & yes \\
\hline Shirley & 48 & Mobility ,Hearing & Scotland & Divorced & no \\
\hline
\end{tabular}

All women became involved in the project through a process of self-selection. Disch (2001) asserts the importance of research participants being able to freely volunteer themselves for involvement in the research. Although this method would not produce a representative cross section of the disabled female population, Booth and Booth (1997) maintain how such bias is permissible as it reduces the difficulties that could emerge from third party explanations of the research. Further it confirms that the disabled women were in the right place in terms of their personal healing and confident about speaking out and sharing their realities.

Short recruitment notifications were published on the project website, on Facebook, and in newsletters of disabled people's organisations (such as Inclusion Scotland) across the U.K. A number of women responded to these. Other women leaned about the work through their association with some of the expert service providers involved in the second and third empirical phases of the project. For example, five of the women attended monthly support 
groups for disabled women which were led by one of experts interviewed for the second empirical phase. One disabled woman was on the board of trustees of another of the specialist services involved in the research. Another woman had just won a court case against her perpetrator with the specialist support of one of the experts (who is also a member of the project advisory board). The final sample was made up of women based in different parts of England and Scotland.

Once the women had expressed an interest in participating in the research, they were sent a Participant Information Sheet and Consent Form. Completion of the former provided some important information about the participant to ensure she meets the sample criteria before interviews are arranged. It also provided space for participants contact details (according to their preference) so the researcher could keep them informed about the project as it developed. The women were also requested to provide alternative names for themselves, so their identities could be protected if they gave consent for their stories/ experiences to be disseminated in publications and reports. The Consent Form allowed them to give written consent. However, written consent was normally acquired after the interview had taken place and the researcher had verbally explained the aims and objectives of the research, and how the women's stories would be used. Higgins and Swain (2010) propose that the process of explanation is important as it influences the acquisition of informed consent. The researcher tried to be as open and honest as possible in her explanation of the research, and allowed the women to hold the reins to the interview research process. Although the researcher guided the women through the interview with a very open topic guide, ultimately the women had control over how and if they responded to these questions. Further they determined if they wanted a break and when to resume the conversation. This was especially important given the sensitive nature of the topic.

\section{Use of Empathy}

Most of the interviews were conducted by the first author of this paper, who is herself a disabled woman. It can be argued that her ontological position, as a disabled female researcher, was key to the development of this research. Leicester (1999) and Oakley (1981) suggest that interviewing individuals with similar experiences encourages the generation of richer material. Stanley and Wise (1993: 227) describe this experience of knowing as an “epistemological privilege," with researchers having access to a priori knowledge of their informants' subjective realties by virtue of their shared experiences. 
The researcher and the researched shared the identity of being disabled women and the experiences of simultaneous oppression it engenders. This was helpful in terms of recruiting participants, and building rapport with them, encouraging them to be more open. Nosek et al (2001) concurs with this, suggesting that a non-disabled interviewer may create psychological divide when interviewing a disabled woman. However they also point out that although a disabled interviewer may establish rapport with disabled participant more rapidly, their shared experiences could cause them to digress away from the interview agenda. During her $\mathrm{PhD}$ training, the disabled researcher had been made aware of the dangers of 'overrapport', and, taking Moser's (1958:187-188) advice, adopted a 'pleasantness and a business-like nature'. Further, the researcher did not have any experience of abuse herself, and thus was able to retain a fair level of objectivity when interviewing the women. Bondi (2003) contends that some level of objectivity is important as it enables the interviewer to be emotionally present and reactive to the interviewees' responses while simultaneously staying in touch with, and reflecting on their own feelings. In this way there is not a danger of the interviewer becoming unconsciously overwhelmed by the respondents' stories, reacting to rather than reflecting on what is going on, and blurring the interviewer/ interviewee boundary (see Shah, 2006).

\section{The Interview}

Once the women had responded to the recruitment request and completed the Participant Information Sheet mentioned above, arrangements were made, between themselves and the researcher, for the interview. The women were presented with options as to what format of interview would be most accessible for them - face-to-face, via e-mail, via skype, telephone. All women expressed a preference for face-to-face interviews.

The location of the interviews was chosen by the disabled women. Most of them expressed a preference to hold interviews in their own home which was considered safe and accessible for them. In cases where women felt this was not appropriate, they were interviewed in a women's support service which was local and familiar to them. Arrangements for this were made through negotiations between the researcher and thee relevant expert service providers. Service providers also offered to provide support to the women, if they required it, as a consequence of being re-traumatised by the interview. Only one of the interviews was conducted in a public place (bar/restaurant) as it was convenient for the participant. The possible problems of discussing such a private and sensitive topic in such a public place were 
noted but the participant was not concerned. In the event, no problems were encountered. The only problem related to the transcription of the interview which was occasionally difficult due to background noise.

All interviews were between 60-120 minutes in duration. However breaks were incorporated into the interview time for different reasons including because the participant requested some time to regain her emotional composure after recollecting traumatic experiences, they need a comfort break or because they were needed to provide assistance to someone else. For instance, one of the women described herself as a full-time carer to her eighty year old mother who had Alzheimer's and thus needed to interrupt the interview when her mother needed personal assistance.

\section{Research Findings}

Drawing on the data from the six selected case studies, this section of the paper will present the disabled women's reflections in relation to the different types of violence they encountered at different points in their lives including impairment specific violence, their experiences of the formal and informal support mechanisms they drew upon at these times, and their own aspirations for the protection of disabled women/ girls who have survived violence and the prevention of such violence in the future. In this regard, three key themes will be discussed here: 'Experiences of violence over life', 'Access to support' and 'Future Aspirations' to exemplify the reality for disabled women who are survivors of violence.

\section{Theme 1: Experiences of violence over life}

According to the disabled women in the sample the situation of violence encompassed several things including Physical and sexual violence, emotional abuse or economic coercion. Physical violence was seen in terms of being hit and beaten, psychological or emotional violence involved being verbally attacked, physically isolated from others, being conditioned to feel worthless by the perpetrator saying and doing things to purposely lower the woman's self esteem and confidence.

Women gave examples of the types of violence they encountered at different points in their life course, from childhood to adulthood. For example Barb recalls being violated at different stages of her life, from the age of about eight: 
I think at different stages through my life there's been things that have happened. Sort of as a child I remember being, I suppose you could call sexual assaults, when I was about eight years old. Then in my marriage, I was married at 17, my husband was physically violent to me maybe about 4 times. And then the longer relationship that I had later on was everything: physical violence, sexual violence, emotionally and I tend to see a sort of mental torture that's quite different, it's a sort of extreme of the emotional abuse. It was really really bad, to the point where it was absolute mental torture. (Barbara)

Samantha reflects on the violence she was subjected to over her life by different male perpetrators, starting in childhood by her brothers, who beat her. At the age of nineteen/twenty she was forced, by her brothers, to marry a much older man who also abused her:

in those days we couldn't say nothing to our parents. My mum died when I was two and my dad died when I was sixteen. My brothers used to beat us up a lot; maybe because they wanted to be - yes, in other words that's right - they wanted to be in control. They were controlling us, they were controlling all the sisters. All my three brothers... They arranged or forced my marriage because my dad had passed away when I was sixteen. I was twenty at the time and he was about forty; or he could have been sixty. You know he never told me his age! And for the sake of me starting to talk to my sisters and my brothers I got married but I stayed in India for ages; eight months. They wouldn't let me - my husband wouldn't let me come back to England. I tried to commit suicide a couple of times and they [the husband's family] just got fed up and sent me back to England.

Lois also recalls experiencing abuse by a male member of her family. Her experience was longitudinal, starting during childhood and ending in early adulthood. Like Sam she tried to eliminate the memories of the violence, and the psychological scars it caused. However she did this through alcohol as opposed to attempted suicide:

when I was about six-seven and thirteen I experience abuse from an extended family member... when I was about 14 or 15 , I was raped, but maybe one or two friends knew about that but no one really knew it didn't come out in full until I was 18 or $19 \ldots$ I used to have to drink a pint glass of wine before I go to sleep and that was usually in combination with a lot of my medication as well, so that would be how I would get to sleep without worrying. I used to not being able to handle being in any sort of silence and cope with it because of my mind would take over and get trapped and think really negative.

Some of the women experienced impairment-specific abuse, a type of violence not experienced by non-disabled women. This type of abuse took place out of sight. It was related to isolation, control and manipulation. For example, Adele recollects how she experienced abuse for a good part of a decade, starting when she was a young teenager. The perpetrator, who was in their 20s at the time, was Adele's carer and sexual partner. Adele 
believes that the perpetrator definitely took advantage of the fact she had an impairment to abuse her. However, at the time she did not recognize it as abuse:

\begin{abstract}
He would tell friends that I was poorly when he'd zonked me out. If you've had very strong painkillers, you're very dozey; so he would purposefully give me the strongest painkillers when my friends were coming, and they couldn't come then obviously because I was asleep. He would cancel care shifts, he would then say that I'd cancelled them, because again when you've had them tablets you're not good at remembering anything - even what your name is... he'd give you so much that you didn't know what you'd done...I just woke up and I thought I might have smacked myself in the eye. Now luckily I'm not with him anymore. But, like now, my mates know if I've smacked myself in the eye. Before now, I didn't really know what he did to me which is probably the worst thing actually.
\end{abstract}

Alison, another participant, was victim of physical, psychological and financial abuse. She identified some of the violence she experienced by her three husbands as related to her being disabled. She believes all of them saw her as an easy target and easy to control:

My first husband saw me as a meal ticket because of my impairment...My husband, at the time, isolated me from my peers so I felt so alone...It was about control; if you're abusive it doesn't matter where the abuse leads it's always about control. They've got a manual, they've got the same book; you can laugh but they have

\title{
Theme 2: Access to support
}

The women mentioned different kinds of support they tried to access at different times. This was both formal and informal, resulting in positive and negative outcomes. There were several examples of women experiencing barriers to accessing support over their lives. These barriers were caused by different individuals and structures. For instance, both Barb and Lois remembered how their own families avoided formally reporting the abuse they experienced for fear of the scandal it may create:

I think the thing that hurts me the most was probably my parent's reaction - my mum particularly, I think they must have been thinking do they phone the police, if they do, you know, it'd be a big scandal; it would be in the paper - all this kind of thing. A sort of shameful situation and I remember hearing my mum saying that "she's young, she'll just forget about it if we don't mention it". And it was just swept under the carpet. (Barb)

Lois was sexually abused by her cousin from when she was age seven to thirteen. Although it was made known to her immediate and extended family, her family was frightened of the scandal it may cause within their community and thus preferred not to formally report it to the police at the time. When Lois was 18 and went to the police herself, she felt she was not 
fully believed because her parents "were in denial" and thus "skipped over what was important" in the reports they gave.

Alison tried various avenues of formal support for the domestic abuse she was subjected to by her husbands. However she faced disabling attitudinal barriers by support services which resulted in her children being removed from her for a while:

I did try but they just didn't grasp it [...] and when I did turn to anyone for help it went all wrong so in the end I nearly lost the kids, I did lose the kids for at least a while... Me: I was branded as the worst mum in the world

Despite the fact Alison was experiencing on-going violence from partners, she could not access formal or informal support. She requested to be relocated for her and her children's safety, but there were no services that offered support for her as both a disabled woman and mother :

all I needed was a helping hand to say: "here you are; here's a place, here's some money, and with your kids - we're going to give you some support. We'll find you a job, or a job interview even, we'll start you on your way and then it's up to you. That's all I needed

Barb also had to put up with years of severe abuse from her second husband. This started in 1988:

I'm don't know how I got into this situation but it turned out to be sixteen years long and it ws just very very bad; violence, sexually violence; rape, hundreds of times literally. Just completely broke me down and I just think that people understand that there's abuse and there's just absolute torture in it's extreme form and that's where the relationship went.

Barb's husband had isolated her from her family and friends for years, since the late 1980s. She knows that neighbours and the police were aware of the high level of domestic abuse she was being subjected to, but they were waiting until she cried for help. They did not seem to understand that years of abuse and intrinsic fear for herself and her children meant she lacked the confidence to make a formal complaint. This unfortunately meant the police were not prepared to charge the perpetrator and he was free to continue to victimise Barb again and again:

... I don't think I told anyone but lots of people knew because there was a lot of police involvement and things. I was quite seriously injured a number of times and hospitalised a number of times... I think in some ways that the attitude of the police could also be a huge problem because in some ways I felt that they looked on me as being just as bad because I wouldn't do something about it; you know sort of 
"how do you expect us to help you if you wont help yourself?" Yes, that's fine but I couldn't help myself. I don't think they were able to sort of understand this prisoner of war camp that I had going on. You know I remember at the very end when I was finally leaving the police put it too me that "you know we've tried to help you so many times." At this point I was actually going, I'd left the house and I was asking them to help me and the inspector was like "Why should I put my officers at risk so you can go home and play happy families tomorrow?" ...

Lois also wanted assistance from the police but felt her drinking and sexually promiscuous behaviour, adopted as mechanisms over the years to cope with the scars of abuse, would be used as negative evidence and reduce the likelihood they would help her:

I felt I couldn't go to the police because I felt I'd be scrutinized and I felt that everything that I'd done ever since would be used as evidence against me and because I felt all is based on your character and instead of being believed and because of the way I behaved in the time since what has happened to me, I felt like people would say it's my fault or I brought it on myself or that I have to go to court and explain things... I thought it would be very easy for anyone to say well of course with how much you have drunk at the time

In Barb's case, however, eventually the police did take positive action and persuaded her to leave the abuse situation:

by 2004 the police weren't just going to go away, they were coming in. And you know the police then did press charges against him, regardless of what I said, based on what they could see. So I think whether there'd been changes in legislation during that time or the approach that the police would take; the sort of guidelines that they worked within

This could have been prompted by several things, including the approach taken by successive U.K. governments to tackle domestic violence by policy development (such as the Sexual Offences Act, 2003, and Domestic Violence, Crime and Victims Act 2004), and Barb's own agency and self-confidence to negotiate her own escape routes. She believes that becoming employedin a support service for people with her impairment provided her with opportunities to learn about similar cases and support mechanisms. She also befriended someone from work with whom she confided:

In January my friend and her husband drove me to my kids school and picked them up and we ran. My three youngest children we got from school and we went into refuge with Women's Aid. And that was the last time we ever went back there

In another case, Shirley reveals how she was continuously physically abused, by her father when she was growing up in New York City in the 1970s. She believes that part of the 
problem was children did not have many rights, as they do today. This was prior to the Children's Act and when child abuse was a private affair not a public matter:

When I was 14, I called something called Child Protection Services, in New York City in America and I was told I would be entitled to Family Counselling. I said that I thought my father was a danger to me and that he was excessively violent, and that I was in fear of something horrible happening to me like him putting me in hospital. And I was still pretty much fobbed off, and it was the family counsellor who said that until he did something quite nasty that would put me in hospital they could not do anything.

Even where her scars were obvious, professionals failed to believe Shirley was being abused, and thought she was the cause:

they (hospital staff) thought I was a heroin addict 'cause I was so thin and I had needle scratches because I was having medication and I was also having convulsions and with the convulsions they made assumptions and thought that I was a heroin addict and they treated me like a piece of dirt .... I collapsed on the floor and I was there for an hour and I then crawled back to my room and then I lost consciousness and was in a comma and they had to give me an adrenalin shot and I still have the scar.

On a more positive note, both Adele and Samantha discovered a support service in their home city that specialised in providing support to disabled women. It was run by a disabled woman, herself a survivor of domestic violence. The two women believed that, joining the service and meeting other disabled women who had experienced what they had caused a turning point for both of them. It provided them with a means to regain their confidence enough to be able to stop what was happening to them. For instance, after being in an abusive relationship for 10 years, Adele decided it was time to get out. She speaks of how meeting the manager of the disabled women's support service prompted her to do so:

I was 23 when I started trying to get out of it but it takes a lot of time. I think to get to the point where you can't stand it anymore. You try to change it but then it doesn't change and you have to get out... she (the manager) was talking about smear tests and stuff like that. Then afterwards she started talking about this: domestic violence towards women, and it just sort of clicked into place that I've got to go, he's got to go. Even if I had to go back to my parents he's got to go.

\section{Theme 3: Future Aspirations}

At the end of each life history interview the women were asked 'If you had a magic wand what would you wish for to protect disabled women and girls from violence'. Several of the women emphasized the importance of education and training to promote an awareness of the consequences of violence for both the abused and the abuser. Also there was a perception that 
through disability awareness members of society could learn acceptable and unacceptable treatment for disabled people, and how it should not be different to what is acceptable and unacceptable for non-disabled people/children.

\begin{abstract}
Alison suggests that disabled girls should be given sex education in schools, be these segregated or mainstream. This should include knowledge about the difference between right and wrong sexual behaviour, information about their entitlement to resist anything they do not like no matter who the perpetrator is, and advise about how to report any wrong behaviour.
\end{abstract}

The last word is from Barb, again in relation to education and ensuring women can access the right information:
I know that nowadays the health visitor will talk to new mums about postnatal depression. Well maybe the subject of violence in a relationship could be covered at that stage; just really getting the information to women. If it hadn't been for my work I wouldn't have known that there were people out there that could help and when it came to it for me the obvious people like the police didn't give me that help initially; I had to do it for myself. Yes, educating people and getting the information to people would help

\title{
Conclusion
}

This paper brings the voices of disabled women to the forefront of debates on violence against women and on disability, two areas of research and policy which have marginalised the experiences of disabled women. It discusses the reality that disabled women are significantly more likely to experience violence compared to their non-disabled contemporaries, at the hands of different perpetrators, including paid and unpaid carers, and in various ways including those specific to their impairment. Drawing on preliminary evidence from life history interviews with disabled women based in the U.K., the paper suggests how disabled women and girls experience particular types of violence specific to their impairment which is often not recognised as violence (by professionals or even the women themselves) but rather part of the everyday life of a disabled person. Further the paper highlights how disabled women are at the intersection of gender and disability bias and, as a result, likely to encounter a range of barriers to support. Such barriers are influenced by a number of factors including: historical perceptions of disabled women as asexual and incompetent as sexual partners or mothers, being dependent on perpetrators for personal care, physical inaccessibility of specialist support systems and the disbelief women face when 
reporting their experiences to professionals. However, regardless of these barriers, the disabled women, introduced in this paper, are all survivors because they drew on other support mechanisms, including their own agency, and support from, and identification with, other disabled women.

The article explored concepts of empathy and identification, highlighting how personal ontological research resources have not only become recognized as valid sources of scholarly knowledge and also as a means to enable respondents to share experiences with an empathic other (Shah, 2006; Riessman, 1994). As Karl (1995) observes, a sense of empowerment comes from being respected and recognized as equal citizens with a contribution to make.

Facilitating disabled women to speak out for themselves about their experiences of violence and support over the lifecourse can contribute to the development of future policies and practices in educational institutions and specialist support services. Learning from insider perspectives are crucial to develop tailored mechanisms to reduce the prevalence of violence against disabled women and girls in the future.

\section{Acknowledgements}

The authors would like to thank the disabled women who participated in the project on which this paper is based.

\section{Funder}

The work was supported by the European Commission [grant number: JUST/2011-2012] 


\section{References}

Adoption and Children Act (2002). (c23) London: the Stationary Office

Atkinson, R. (1998). The life story interview. London: Sage.

Balderston, S. (2014). Victimised again? Intersectionality and Injustice in disabled women's lives after hate crime and rape. Gendered Violence: Macro and Micro Settings. Advances in Gender Research, 18, 17-51.

Begum, N. (1992). Disabled women and the feminist agenda. In H. Hinds, A. Phoenix, and J. Stacey. (Eds.) Working out: New directions for women's studies (61-73). London: Falmer.

Barron, K. (2010). Bumpy road to womenhood. Disability and Society, 12, 2, 223-240.

Bashall, R. and Ellis, B. (2012) Nothing About Us Without Us: Policy and Practice. In Thiara, R., Hague, G., Bashall R., Ellis, B. and Mullender, A. (Eds.) Disabled Women and Domestic Violence: Responding to the Experiences of Survivors (106-136). London, Jessica Kingsley Publishers.

Belsky, J. (1980). Child maltreatment: An ecological integration. American Psychologist, 35, 4, 320-335.

Bertaux, D. (1981). From the life-history approach to the transformation of sociological practice. In Bertaux, D. (Ed.). Biography and Society: The life history approach in social sciences (29-45). London: Sage.

Booth, T. and Booth, W (1997). Making connections: A narrative study of adult children of parents with learning difficulties. In Barnes, C. and Mercer, G. (Eds.) Doing Disability Research (123-140). Leeds: Leeds University Press.

Booth, T. and Booth, W (1994). Parenting under pressure: mothers and fathers with learning difficulties. Buckingham: Open University Press

Bondi, L. (2003). Empathy and Identification: Conceptual Resources for Feminist Fieldwork. ACME: An International E-Journal for Critical Geographies, 2, 1, 64-76.

Campling, J. (1981). Images of Ourselves. London: Routledge \& Kegan Paul.

Cockram, J. (2003). Silent Voices: Women with Disabilities and Family and Domestic Violence. Nedlands, WA: People with Disabilities (WA) Inc.

Curry, M. A., Hassouneh-Phillips, D., \& Johnston-Silverberg, A. J. (2001). Abuse of women with disabilities: An ecological model and review. Violence Against Women, 7, 60-79.

Disability Discrimination Act 2005. (c.13). London: The Stationery Office

Disch, E. (2001) Research as clinical practice: creating a positive research experience for survivors of sexual abuse by professionals. Sociological Practice. : A Journal of Clinical and Applied Sociology, 3, 3, 221-239. 
Domestic Violence, Crime and Victims Act (2004). (c.28). London: The Stationary Office http://www.legislation.gov.uk/ukpga/2004/28/contents [26.3.13]

Equality Act 2010 Section 193 http://www.legislation.gov.uk/ukpga/2010/15/section/193 [17.4.13]

European Parliament resolution on the situation of people with disabilities in the enlarged European Union: the European Action Plan 2006-2007. (2006-2007 (INI))

Family Law Act (1996). (c.27). London: The Stationary Office

Finkelstein, V. (2001). The social model of disability repossessed. Retrieved January 2007, from http://www.leeds.ac.uk/disabilitystudies/archiveuk/finkelstein/soc\%20mod\%20repossessed.pdf

First international treaty to afford disabled people human rights: http://www.un.org/disabilities/convention/conventionfull.shtml

Forced Marriage (Civil Protection) Act 2007 http://www.legislation.gov.uk/ukpga/2007/20/contents [21.3.13]

Forced Marriage. (Protection and Jurisdiction) (Scotland) Act 2011 http://www.legislation.gov.uk/asp/2011/15/contents/enacted [26.3.13]

French, S. and Swain, J. (2006). Telling stories for a politics of hope, Disability and Society, $12,1,21-36$.

Hague, G. , Thiara, R.K. and Mullender, A. (2011). Disabled women and domestic violence: Making the links, a national UK study. Psychiatry, Psychology and Law, 18,1, 117.

Higgins, M. and Swain, J. (2010). Disability and child sexual abuse: Lessons from Survivors Narratives for Effective Protection, Prevention and Treatment. London: Jessica Kingsley.

Homelessness Act (2002). (c.7). London: The Stationary Office

Housing Act (1996). (c.52). London: The Stationary Office

Jennings, C. (2003). Violence and women with a disability break down the barriers. Available at www.wwda.org.au/jennings1.pdf, accessed on $8^{\text {th }}$ April 2014.

Karl, M. (1995). Women and Empowerment: Participation and Decision Making. New Jersey: Zed Books.

Kelly, L., Regan, L. and Burton, S. (1991). An Exploratory Study of the Prevalence of Sexual Abuse in a Sample of 16-21 Year Olds. Child Abuse Studies Unit. London: PNL. 
Kennedy, M. (1996). Sexual abuse and disabled children. In Morris, J. (Ed.) Encounters with Strangers. Feminism and Disability (116-134). London : The Women's Press Ltd.

Leicester, M. (1999). Disability Voice - towards an enabling education. London, Philadelphia: Jessica Kinsley Publishers.

Martin, S. L., Ray, N., a Sotres-Alvarez, D., Kupper, L.L., Moracco, K.E., Dickens, P.A., Scandlin, D. and Gizlice, Z. (2006). Physical and Sexual Assault of Women with Disabilities. Violence Against Women, 12, 823-838.

Ministry of Justice http://www.justice.gov.uk/ [26.3.13]

Morris, J. (1996). (Ed.) Encounters with Strangers: Feminism and Disability. London: The Women's Press Ltd.

Moser, C. A. (1958). Survey Methods in Social Investigation. London: Heinemann.

Nosek, M., C. Howland, and R. Hughes. (2001). The investigation of abuse and women with disabilities: Going beyond assumptions. Violence Against Women 7, 4, 477-499.

Oakley, A. (1981). Interviewing women: A contradiction in terms. In H. Roberts (Ed.). Doing feminist research (30-61). London: Routledge.

Priestley, M. (2003). Disability: A life course approach. Cambridge: Polity Press.

Protection from Harassment Act 1997 http://www.legislation.gov.uk/ukpga/1997/40/contents [4.4.13]

Protection of Freedoms Act 2012

http://www.legislation.gov.uk/ukpga/2012/9/contents/enacted [29.4.12]

Riessman, C. K. (1994c). Subjectivity Matters: The Positioned Investigator. In Riessman C.K. (Ed.) Qualitative Studies in Social Work Research (133-138). London: Sage.

Saxton, M., Curry, M.A., Powers, L.E., Maley, S., Eckels, K. and Gross, J. (2001). 'Bring my scooter so I can leave you': A study of disabled women handling abuse by personal assistance providers. Violence Against Women, 7 ,4, 393-417.

Schröttle, M. and Glammeier, S. (2013). Intimate Partner Violence Against Disabled Women as a Part of Widespread Victimization and Discrimination over the Lifetime: Evidence from a German Representative Study. International Journal of Conflict \& Violence, 7, 2, 233-248.

Sexual Offences Act 2003 http://www.legislation.gov.uk/ukpga/2003/42/contents [26.3.13]

Shah, S. (2006). Sharing the same world: The Researcher and the Researched. Qualitative Research,6, 2, 207-220. London: Sage.

Shah S., Priestley M. (2011). Disability and Social Change: Private Lives and Public Policies. Bristol: Policy Press. 
Shakespeare, T. (2014). Disability Rights and Wrongs Revisited. $2^{\text {nd }}$ ed. Abingdon: Routledge.

Shakespeare, T., Gillespie-Sells, K. and Davies D. (1996). The Sexual politics of Disability: Untold Stories. London: Cassell.

Sobsey, D., Randall, W. and Parrila R.K. (1997). Gender differences in abused children with and without disabilities. Child Abuse and Neglect, 21, 8, 707-720.

Sobsey, D., and T. Doe. (1991). Patterns of sexual abuse and assault. Sexuality and Disability, 9, 3, 243-59.

Stanley, L. and Wise, S. (1993). Breaking Out Again: Feminist Ontology and Epistemology. London: Routledge.

Sullivan, P. and and Knutson, J. (2000). Maltreatment and disabilities: a population based epidemiological study. Child Abuse and Neglect, 24, 10, 1257-1273.

Thiara, R. K., Hague G., Bashall R., Ellis B., Mullender, A. (2012). Disabled Women and Domestic Violence: Responding to Experiences of Survivors. London: Jessica Kingsley Publishers.

Thomas, C. (1999). Female forms: Experiencing and understanding disability. Buckingham: Open University Press.

United Nations Convention on the Elimination of all Forms of discrimination Against Women Seventh Periodic

Reports of States Parties: United Kingdom of Great Britain and Northern Ireland (2013) http://daccess-ddsny. un.org/doc/UNDOC/GEN/N11/648/56/PDF/N1164856.pdf?OpenElement [accessed $4^{\text {th }}$ April 2014]

UN (2006) Convention on Rights of Persons with Disabilities. Available at:

http://www.un.org/disabilities/default.asp?navid=12\&pid=150 (accessed $21^{\text {st }}$ April 2014)

UN Convention on the Rights of a Child (1992)

https://www.gov.uk/government/policies/creating-a-fairer-and-more-equal-

society/supporting-pages/the-united-nations-convention-on-the-rights-of-the-child-uncrc

Westcott, H. and Cross, M. (1996). This far and no further: Tending the abuse of disabled children. Birmingham: Venture Press.

Womendez, C. and Schneiderman, K. (1991). Escaping from abuse: Unique experiences for Women with Disabilities. Sexuality and Disability, 9, 3, 273-280.

Women's Aid (2007). What is domestic violence? Available at www.womensaid.org.uk/domestic-violencearticles.asp? section $=00010001002200410001 \&$ itemid $=1272 \&$ itemTitle $=$ What + is + domestic + violence Accessed $28^{\text {th }}$ March 2014. 
Women's Aid Protection under Criminal Law (2008)

http://www.womensaid.org.uk/domestic-violencearticles.asp? itemid $=1401 \&$ itemTitle $=$ Protection + under + criminal + law \&section $=00010001002$

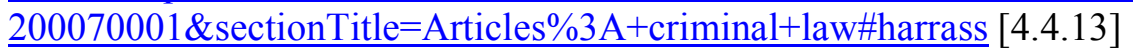




\begin{abstract}
Violence against women is a worldwide social and human rights problem that cuts across cultural, geographical, religious, social and economic boundaries. It affects women in countries around the world, regardless of class, religion, disability, age or sexual identity. International evidence shows that approximately every 3 to 5 women experienced physical and/or sexual violence by an intimate partner. However, across the globe, women and girls with impairments or life-limiting illnesses are more susceptible to different forms of violence across a range of environments and by different perpetrators including professionals and family members as well as partners. However they are likely to be seriously disadvantaged in gaining information and support to escape the abusive relationships. This paper stems from the UK part of an ongoing four country comparative study (2013-15) funded by the European Commission. It presents preliminary findings, generated from life history interviews, about disabled women's experiences of violence and access to support (both formal and informal) over their lifecourse, and their aspirations for the prevention of violence in the future. The paper includes examples of impairment-specific violence not experienced by non-disabled women. By bringing the voices of disabled women into the public domain, the paper will facilitate a historically marginalised group to contribute to the debate about disability, violence and support.
\end{abstract}

\title{
Introduction
}

Internationally and nationally, violence against women has been recognized as one of the most serious forms of gender-based violations of human rights. Estimations from the Council of Europe suggests that between one fifth to one quarter of women across countries in Europe experience domestic violence at some point during their lifetime. Historically, violence against women has been conceived as a manifestation of the unequal power relations between men and women which has led to the discrimination and oppression of women, and their subordination in relation to men. Women and girls are exposed to different forms of violence over their lifecourse. This includes domestic violence, rape, sexual harassment, forced marriage, 'honor' killings and genital mutilation. Such violations of females have been recognized as a worldwide social and human rights problem that cuts across cultural, geographical, religious, social and economic boundaries affecting women in countries around 
the world, regardless of class, religion, disability, age or sexual identity. According to the United Nations, violence against women and girls is defined as:

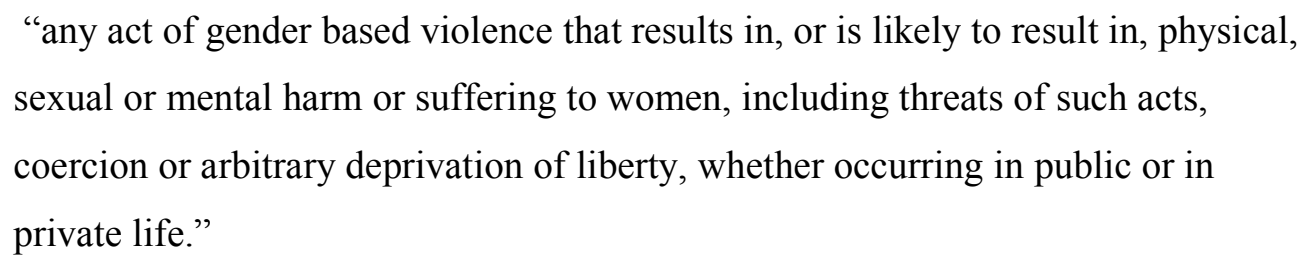

In the U.K. the concept of domestic violence is informed by Women's Aid, a national charity working to end violence against women in the U.K. With a network of 350 domestic and sexual violence services across the U.K., Women's Aid defines domestic violence as: "physical, psychological, sexual and financial violence that takes place within an intimate or family-type relationship and forms a pattern of coercive and controlling behavior. This could include forced marriage and so-called 'honor' crimes. Domestic violence often includes a range of abusive behaviors, not all of which are inherently violent."

(Women's Aid, 2007)

\begin{abstract}
However, many authors have noted that dominant definitions of violence focus on the experiences of violence by non-disabled women, but fail to represent those of disabled
\end{abstract} women even though there is a plethora of evidence to suggest that disabled women and girls are more susceptible to systemic and individual violence across their lifecourse compared to their able-bodied counterparts (Schröttle and Glammeier, 2013; Thiara et al, 2011). Studies conducted in Europe, North America and Australia have shown that over half of all disabled women have experienced physical abuse, compared with one third of non-disabled women (UN, 2006). Nearly $80 \%$ of disabled women have been victims of psychological and physical violence, and are at a greater risk of sexual abuse than non-disabled women (European Parliament, 2006). Balderston (2014) suggests that in the United Kingdom, disabled women are two to five times more likely than men and non-disabled women to experience sexual violence $^{1}$. Further, several studies report that disabled children are approximately three times as likely to be sexually abused than non-disabled children (Sullivan and Knutson, 2000). Accounting for gender, Sobsey et al (1997) found that significantly more disabled girls than 
disabled boys were likely to experience sexual abuse. This supports the work of Kelly et al in 1991 which suggested that one in four disabled boys and one in two disabled girls experience some form of sexual abuse before their eighteenth birthday.

This high proportion of disabled women exposed to and experiencing violence over their lives could be associated with a number of factors, including the fact they are perceived as dependent asexual beings who cannot achieve the goals of womanhood - of engaging in healthy sexual or romantic relationships and of fulfilling traditional gender roles of wife and mother (Bagum, 1992). Thiara et al (2012) suggest that the perception that disabled females are not 'proper' sexual beings women could lead to them being at greater risk of sexual abuse. Further, Cockram (2003) suggests that the fact disabled women and girls have to depend on others for basic personal and social needs places them at greater risk of abuse compared to non-disabled women. This is evidenced by Barron (2010) who cites the experience of a young disabled woman being offered assistance to the toilet by a male. She contends that while this could be interpreted as the woman being viewed as asexual, it could equally be seen as a way for a potential perpetrator to exploit the dependent nature of the relationship and be intimate with the disabled women who they, in fact, do view as a sexual being.

The objectification of disabled women's bodies across their life course has also been suggested as creating opportunities for the abuse of disabled women. Work by Bagum (1992) suggests that there is a tendency for society to reduce disabled women's bodies to asexual objects which can be controlled and manipulated by others. This is concurred by Belsky (1980) who suggest contributing factors include the cultural devaluation of women and disabled people. Womendez and Schneiderman (1991) point out another significant factor as the lack of opportunities disabled women are given to learn the differences between appropriate and inappropriate sexual behaviour. Other authors point out how disabled girls have had limited exposure to sexual knowledge and opportunities while growing up due to being excluded from the cultural spaces where these exchanges take place, or being constrained by high levels of surveillance (Nosek et al, 2001; Shakespeare et al, 1996; Shakespeare, 2014). This opens up ample opportunities for the abuse of disabled females within institutional practices as well as from different individuals who they interact with over their lives. These include professionals, paid carers, family members and intimate partners. 
For instance, Campling (1981:10) pointed out how her body was manipulated by health professionals when she was young:

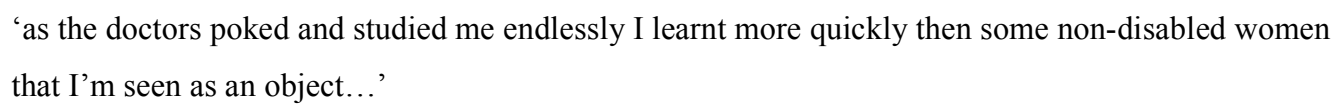

This is similarly evidenced by Thomas' (1999) who presents the narratives of disabled women with different experiences of gender and disability. One of the women's recollection of being routinely exposed to sexual abuse by a male doctor who knew she had no feeling in her lower body, in the name of 'routine check-up', exemplifies the simultaneous oppression resulting from the interplay of disablism and sexism.

Professional, social and institutional practices, as discussed above, have often been taken for granted as a normal part of disabled people's everyday lives, and not considered to be 'abusive practices' in the same way that they would if experienced by a non-disabled child/adult. Work by Westcott and Cross (1996), and Shah and Priestley (2011) draw attention to practices of public stripping, disabled children parading naked in front of medical professional and students who are strangers to them, and medical photography of disabled children and young people, experiences which would not be suffered by non-disabled children. These differing notions of acceptable and abusive behaviour for disabled and nondisabled individuals is reflected in a quote by a Social Services Team Leader in a study by the British Association for the Study and Prevention of Child Abuse and Neglect (1992) (cited in Morris, 1996:117)

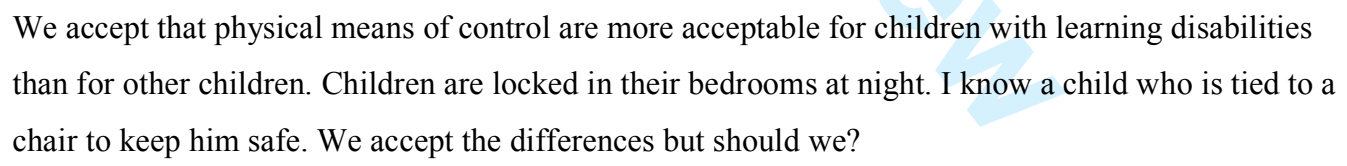

Such attitudes by practitioners create barriers to knowledge, disclosure and reporting in relation to the abuse of disabled children. Kennedy (1996) argues that there is a notion, among professionals, that abuse experienced by disabled children is of less significance than that experienced by non-disabled children. This in itself becomes a barrier to accessing support and protection. For instance, although disabled and non-disabled children are equally manipulated by the perpetrator to blame themselves, the former are less likely to be believed when disclosing the act (Higgins and Swain, 2010). Even when signs of abuse, including sexual abuse, is recognised practitioners seem to associate it with the child's impairment (Kennedy, 1996). 
Although disabled women and girls experience the same types of abuse as their non-disabled contemporaries, they are likely to be subjected to additional types of abuse specific to being disabled. The impairment-specific acts of abuse include those which simultaneously increase the powerfulness of the perpetrators and the powerlessness of the disabled women. Curry et al (2001) highlight experiences such as the misuse of medication, isolating individuals from family and friends, removing the battery from the woman's power wheelchair as forms of abuse that non-disabled women/ girls do not experience. However, as previously mentioned, these practices/ actions may not be seen as abuse, either by professionals or by disabled people themselves. Even when disabled people do feel they are victimized, very few are in a position to report it to the authorities or a women's service such as Women's Aid. Several authors suggest a number of reasons for this, connected to the fact that disabled women and girls are likely to experience additional abuse by people on whom they are reliant, be they family members and paid carers, as well as intimate partners. Sobsey and Doe (1991) report how disabled women are likely to experience additional abuse at the hands of people who are supposed to "care" for them, such as personal assistants, parents, health care workers and staff of residential settings (i.e. schools or care homes). The dependent status of the disabled woman in such situations reinforces the notion that they are incompetent and powerless to resist or report perpetrators' advances, making them more likely to be victimized than nondisabled women (Nosek, et al 2001). This is supported by Saxton et al (2001) who found that disabled women are less likely get support or prevented from accessing other sources of support when they are reliant on their abuser. At the same time, in cases where the perpetrator is also the disabled girl's/ woman's assistant they may be particularly reluctant to make a charge for fear they would be left with no-one to provide the personal care they require to live independently (Martin et al, 2006; Kennedy, 1996).

Apart from the barriers caused by perpetrators, much evidence suggests disabled women face several obstacles when seeking professional support which is open to non-disabled women (Thiara et al, 2012). Such includes the lack of physical access to services, the inaccessibility of publicity materials, lack of accessible alternative accommodation such as refuges, and as suggested above, social stereotypes that assume disabled women to be asexual, tragic or burdens to society. Further, professional's poor understanding of disability and impairmentspecific abuse shape responses to disabled women and frequently leave them without protection from more general sources of support, such as the criminal justice system or other 
legal structures. For instance, disabled women may experience disbelief when approaching service providers about experiences of abuse in relation to their impairment, or even may avoid accessing formal support for fear they would not be believed over the non-disabled perpetrator. Further where children are involved, disabled mothers experiencing violence may not seek professional help for fear they could be perceived as incompetent parents and experience interventions by legal and medical professionals in their reproductive lives (Booth and Booth, 1994; Priestley, 2003). Bashall and Ellis (2013) note how policy makers and society in general do not conceive the impairment-specific acts of abuse as domestic violence or hate crime, but more as "some innate vulnerability caused by their impairment" (p.116). This in itself is a major barrier to prevention and to accessing services and support. Therefore, despite the recognised large numbers of disabled women encountering violence, the obstacles they face, including the legal and protection frameworks that exist to protect women from violence, prevent them from getting the support they deserve to end the abuse in the lives.

So it is clear that continuation of violence of disabled women often stems from the inequalities associated with being disabled and female in a patriarchal society constructed around the non-disabled majority. The intersectionality of disablism and sexism helps to materially locate disabled women on the axis of power and disadvantage, and therefore provides a tool for understanding to complexity of disabled women's experiences of abuse and disadvantage. As Jennings (2003) pointed out:

Women and girls with disabilities live at the intersection of gender and disability bias. As a consequence, they experience higher rates of violence and lower rates of service provision than their non-disabled peers.

However, the historic marginalisation of disabled women, by disablism and patriarchy, means that regardless of the high rates of victimization experienced by disabled women (as suggested by the research reviewed above), their experiences and voices remain absent from policy and research agendas, both in areas of domestic violence and disability. This 'invisibility' from these two camps has, in turn, contributed negatively to the high victimization of disabled women (Cockram, 2003; Thiara et al, 2012). Through the presentation of some preliminary qualitative evidence generated from the U.K. part of an EU funded four country comparative study, the aim of this paper is to examine disabled women's 
experiences of violence and access to support (both formal and informal) over their lifecourse. In this work, disabled women are identified according to the definition outlined by the United Nations Convention on the Rights of Persons with Disabilities (2006):

Women with disabilities include those who have long-term physical, mental, intellectual or sensory impairments which in interaction with various barriers may hinder their full and effective participation in society on an equal basis with others

Through the first-hand accounts of disabled women, this paper will present examples of how women experienced different types of violence including impairment-specific violence. It will highlight the main barriers and enablers to accessing specialist and more general victim support services at different points in the life course. It will also bring forth disabled women's aspirations for the protection of survivors of violence and the prevention of violence against disabled women in the future. In so doing, it will provide the voices of a simultaneously oppressed group with the opportunity to enter the public domain and inform macro-level decisions that impact their lives. Before presenting this data, the paper will briefly discuss the legal instruments, both international and U.K. based, which currently exist in relation to violence against women in general and disabled women in particular.

\section{Law and Policy}

Acts of violence, once seen as a more private matter, have prompted the development of various international and national legal human rights instruments to protect women and girls from harm and abuse. With over three million women affected by a different acts of violence and abuse the UK government has signed up to main international treaties related to violence against women and on the rights of disabled people. National legal instruments have also been developed in the relation to violence against women and disabled people in the U.K. However, a policy review conducted as part of the first phase of the EU research study mentioned above revealed noticable gaps in existing legislation in relation to disabled women. This section will briefly discuss some of the international and national legal instruments relevant to violence for women in general and for disabled women in particular. It is by no means an exhaustive list. 
In 1989 the Convention on the Rights of a Child was the first international treaty proposed to protect the rights of children under age 18. With 54 articles it sought to cover a range of human rights including the protection from violence (Article 19). The UN also developed other instruments in relation to protection and prevention of violence against women. UK government signed the Convention on the Elimination of All Forms of Discrimination against Women (CEDAW) on 22 July 1981 and ratified it on the 7 April 1986. Further to this the UK acceded the CEDAW Optional Protocol (OP) on the 17 December 2004 and it entered into force on 17 March 2005. The Ministry of Justice ${ }^{2}$ has responsibility for its implementation in the UK. The Treaty has had symbolic importance in influencing the development of other laws and policies in the UK as well as allowing the government to be held to account through the relevant provisions of General Recommendations 19, 14 and 24. A number of reservations remain in place, for Articles 9, 11, 15 and 16. In 2002 The Adoption and Children Act amended the 1989 Children Act, amending the definition of 'significant harm' to reflect the impact of domestic abuse on children. In December 2003 the Protocol to Prevent, Suppress and Punish Trafficking in Persons, especially Women and Children entered into force. It supplemented United Nations Convention Against Transnational Organised Crime. The protocol states to prevent and combat trafficking in persons, and protects victims of trafficking. The prevention and protection of trafficked persons includes women and children who are trafficked for commercial sexual exploitation. The protocol was acceded by Council of Europe that opened a Council of Europe Convention on Human Trafficking signed by U.K. in 2005. Although complementary protection is ensured through the Lanzarote Convention on the Protection of Children against Sexual Exploitation and Sexual Abuse (2007), the thirty signatories does not include the U.K. as yet.

As well as law and policy with respect to women in general, there is also law and policy in relation to disabled people which seeks to protect the rights of disabled people, with articles specific to disabled women. The UN Convention on the Rights of People with Disabilities $(\mathrm{UNCRPD})^{3}$, is the first international treaty to promote the civil rights of disabled people in all aspects of social life. Articles 6, 15, 16 and 17 are particularly relevant to this topic. In Article 6, the UNCRPD recognises that disabled girls and women encounter multiple

\footnotetext{
${ }^{2}$ Ministry of Justice http://www.justice.gov.uk/ [26.3.13]

${ }^{3}$ First international treaty to afford disabled people full human rights: http://www.un.org/disabilities/convention/conventionfull.shtml
} 
discrimination and propose to take measures to ensure they can enjoy their human rights. Article 15 proposes to take legislative and other measures to prevent disabled people from being subjected to torture or cruel degrading treatment. Article 16 is specific to ensuring disabled people are free from violence, exploitation and abuse. Article 17 offers mechanisms to ensure disabled women can retain their mental and physical dignity.

Legal remedies are available in the UK through both civil law, which aims at protection for women experiencing violence, and criminal law, which aims at punishment of the offender. These include the Family Law Act 1996, Homelessness Act 2002 and Housing Act 1996. In 2004, Domestic Violence, Crime and Victims Act came into force to amend Part 4 of the Family Law Act 1996, the Protection from Harassment Act 1997 and the Protection from Harassment (Northern Ireland) Order 1997. It makes many acts of violence arrestable offences including public order offences, assault and battery, threats to kill, harassment, sexual offences, kidnap and child cruelty. Under criminal law, the Protection from Harassment Act 1997 allows a woman who has experienced violence to take out a restraining order that bars the perpetrator from making contact with the survivor. This law aimed at dealing with the problem of stalking, although Women's Aid reports that follow up research revealed $40 \%$ of the worst offences involved harassment by ex-partners. ${ }^{4}$ In 2012 this Act was updated by the Protection of Freedoms Act 2012, which made two new offences of stalking and stalking involving fear of violence or serious alarm and distress, also allowing for the police to search premises in relation to these crimes. The Forced Marriage (Civil Protection) Act 2007 protects individuals from being forced into marriage without their free or full consent. It came into force in England and Wales on the 25 November 2008, also covering Northern Ireland, and the Forced Marriage (Protection and Jurisdiction) (Scotland) Act 2011, was passed by the Scottish Parliament on 22 March 2011. Under the provisions of the legislation, a Forced Marriage Protection Order may be issued, prohibiting that a person be taken overseas or ensuring that they are returned to this country. So, although the act of forced marriage itself is a civil offence, it has consequences that are considered which are deemed criminal under other legislation, including the Sexual Offences Act 2003 or Domestic Violence, Crime and Victims Act 2004.

\footnotetext{
${ }^{4}$ Women's Aid Protection under Criminal Law (2008) http://www.womensaid.org.uk/domestic-violencearticles .asp? itemid $=1401 \&$ item Title $=$ Protection+under+criminal+law\&section=00010001002200070001\&sectionTi tle=Articles $\% 3 \mathrm{~A}+$ criminal+law\#harrass [4.4.13]
} 
In terms of legislation specific to disabled women, the Equality Act 2010 amalgamated various laws, including those relevant to disabled people and women. The Disability Discrimination Act 1995 (DDA) set out the first foundations of civil rights legislation for disabled people. According to the Act it is unlawful for any person to subject a disabled person to harassment which has the purpose/effect of violating the disabled person's dignity, or creating a hostile, offensive, humiliating or degrading environment. This is detailed, in Part I of the Act, in accordance to public authorities, including employers, advocates and barristers. DDA 2005 amends DDA 1995. It applies to access to goods and services, including legal services. Individuals with cancer, HIV and mental health difficulties are also covered by the DDA. Further it applies to private clubs as well as public services. Enforcement of accessibility legislation and standards are clearly particularly important in relation to access to specialised services. It may be noted however that charities are exempt from some of the requirements for building accessibility under sections 193 and $194^{5}$. This may include some charities that operate to support women who have experienced violence.

Although the laws and policies, highlighted above, were not explicitly mentioned in the women's survival stories, in some instances they did, albeit indirectly, contribute to their escape and subsequent protection.

\section{Methods}

The aforementioned EU funded research project on which this paper is based adopted a mixed method approach to cover four phases of empirical fieldwork. These phases included an online survey of specialist violence support services across the U.K., semi-structured interviews with key 'experts' (representatives from 15 of the services included in the survey), four focus group discussions with a range of disabled women in different parts of the U.K., and life story interviews with 15 disabled women.

This paper will report on preliminary data from the final phase of empirical fieldwork. It adopted a life story approach to generate data about the social world of a sample of disabled women across the U.K. who are survivors of violence and have experience of specialist support services. According to Atkinson (1998: 8), a life story

\footnotetext{
${ }^{5}$ Equality Act 2010 Section 193 http://www.legislation.gov.uk/ukpga/2010/15/section/193 [17.4.13]
} 
is the story a person chooses to tell about the life he or she has lived, told as completely or as honesty as possible. What is remembered of it, and what the teller wants to know of it, usually as a result of a guided interview by another.

The method of life history interviews to learn about experiences of disabled people, and especially disabled women, is still a relatively new approach (French and Swain, 2006; Shah and Priestley, 2011). It is not only a personal narrative, but offers a unique understanding of development across time (both biographical and historical) and space. As argued by Bertaux (1981) when a life story is told, we not only hear the personal narrative, but also become aware of the interplay between the individual and the broader social structures that gives substance to the narrative and contextualizes it within time and space. Further, life stories offer a mechanism to learn about the experiences of perhaps oppressed or ignored groups (such as disabled girls and women who have survived violence) not ordinarily included in official documentation. In so doing it provides new understandings to existing knowledge on disability and on violence against women/girls, which can challenge assumptions and help to re-examine official documentation about the subject (French and Swain 2006). It also allows a historically marginalised group (disabled women) to become agents of their knowing or knowledge creators.

The life story approach also favours a social model lens and allows a space for nonmedicalised narratives to be voiced by disabled women, providing a space where participants can control when and how they communicate. It allows for the focus to move beyond the 'life experiences of disabled people' and towards the 'experiences of disability in people's lives', responding to Finkelstein's reminder that 'disabled people are not the subject matter of social interpretation of disability' (Finkelstein, 2001: 1). Thus, the primary purpose is to reveal and challenge the network of social relations, institutions and barriers that inhibit the full participation and equality of disabled women when trying to access support for abuse.

\section{Sample and Recruitment}

The target sample included disabled women within age range 18-65, stipulated in the original proposal for reasons relating to ethics and funding. All participants identified themselves as being survivors of violence, and had experiences of accessing support at different points in their lives. The sampled used for illustration in this paper are drawn from six case studies, a sub-set from the larger study. The names have been altered using pseudonyms chosen by the 
participants. The characteristics of the sub-sample such as their age, ethnic origin, marital status and impairment type are summarized in the table 1 below:

\begin{tabular}{|l|l|l|l|l|l|}
\hline $\begin{array}{l}\text { PSEUDO } \\
\text {-NAME }\end{array}$ & AGE & IMPAIRMENT & $\begin{array}{l}\text { REGION, } \\
\text { COUNTRY }\end{array}$ & $\begin{array}{l}\text { MARITAL } \\
\text { STATUS }\end{array}$ & CHILDREN \\
\hline Barb & 47 & Visual Impairment & Scotland & Divorced & yes \\
\hline $\begin{array}{l}\text { Lois } \\
\text { Eldritch }\end{array}$ & 22 & Mobility/Degenerative & England & $\begin{array}{l}\text { In } \\
\text { relationship }\end{array}$ & no \\
\hline Alison & 47 & Mobility & Scotland & $\begin{array}{l}\text { Divorced } \\
\text { and in } \\
\text { relationship }\end{array}$ & yes \\
\hline Adel & 34 & Mobility & England & Single & no \\
\hline Samantha & 48 & Mobility & England & Married & yes \\
\hline Shirley & 48 & Mobility ,Hearing & Scotland & Divorced & no \\
\hline
\end{tabular}

All women became involved in the project through a process of self-selection. Disch (2001) asserts the importance of research participants being able to freely volunteer themselves for involvement in the research. Although this method would not produce a representative cross section of the disabled female population, Booth and Booth (1997) maintain how such bias is permissible as it reduces the difficulties that could emerge from third party explanations of the research. Further it confirms that the disabled women were in the right place in terms of their personal healing and confident about speaking out and sharing their realities.

Short recruitment notifications were published on the project website, on Facebook, and in newsletters of disabled people's organisations (such as Inclusion Scotland) across the U.K. A number of women responded to these. Other women leaned about the work through their association with some of the expert service providers involved in the second and third empirical phases of the project. For example, five of the women attended monthly support groups for disabled women which were led by one of experts interviewed for the second empirical phase. One disabled woman was on the board of trustees of another of the specialist services involved in the research. Another woman had just won a court case against her perpetrator with the specialist support of one of the experts (who is also a member of the project advisory board). The final sample was made up of women based in different parts of England and Scotland.

Once the women had expressed an interest in participating in the research, they were sent a Participant Information Sheet and Consent Form. Completion of the former provided some important information about the participant to ensure she meets the sample criteria before interviews are arranged. It also provided space for participants contact details (according to their preference) so the researcher could keep them informed about the project as it 
developed. The women were also requested to provide alternative names for themselves, so their identities could be protected if they gave consent for their stories/ experiences to be disseminated in publications and reports. The Consent Form allowed them to give written consent. However, written consent was normally acquired after the interview had taken place and the researcher had verbally explained the aims and objectives of the research, and how the women's stories would be used. Higgins and Swain (2010) propose that the process of explanation is important as it influences the acquisition of informed consent. The researcher tried to be as open and honest as possible in her explanation of the research, and allowed the women to hold the reins to the interview research process. Although the researcher guided the women through the interview with a very open topic guide, ultimately the women had control over how and if they responded to these questions. Further they determined if they wanted a break and when to resume the conversation. This was especially important given the sensitive nature of the topic.

\section{Use of Empathy}

Most of the interviews were conducted by the first author of this paper, who is herself a disabled woman. It can be argued that her ontological position, as a disabled female researcher, was key to the development of this research. Leicester (1999) and Oakley (1981) suggest that interviewing individuals with similar experiences encourages the generation of richer material. Stanley and Wise (1993: 227) describe this experience of knowing as an “epistemological privilege," with researchers having access to a priori knowledge of their informants' subjective realties by virtue of their shared experiences.

The researcher and the researched shared the identity of being disabled women and the experiences of simultaneous oppression it engenders. This was helpful in terms of recruiting participants, and building rapport with them, encouraging them to be more open. Nosek et al (2001) concurs with this, suggesting that a non-disabled interviewer may create psychological divide when interviewing a disabled woman. However they also point out that although a disabled interviewer may establish rapport with disabled participant more rapidly, their shared experiences could cause them to digress away from the interview agenda. During her $\mathrm{PhD}$ training, the disabled researcher had been made aware of the dangers of 'overrapport', and, taking Moser's (1958:187-188) advice, adopted a 'pleasantness and a business-like nature'. Further, the researcher did not have any experience of abuse herself, and thus was able to retain a fair level of objectivity when interviewing the women. Bondi (2003) contends 
that some level of objectivity is important as it enables the interviewer to be emotionally present and reactive to the interviewees' responses while simultaneously staying in touch with, and reflecting on their own feelings. In this way there is not a danger of the interviewer becoming unconsciously overwhelmed by the respondents' stories, reacting to rather than reflecting on what is going on, and blurring the interviewer/ interviewee boundary (see Shah, 2006).

\section{The Interview}

Once the women had responded to the recruitment request and completed the Participant Information Sheet mentioned above, arrangements were made, between themselves and the researcher, for the interview. The women were presented with options as to what format of interview would be most accessible for them - face-to-face, via e-mail, via skype, telephone. All women expressed a preference for face-to-face interviews.

The location of the interviews was chosen by the disabled women. Most of them expressed a preference to hold interviews in their own home which was considered safe and accessible for them. In cases where women felt this was not appropriate, they were interviewed in a women's support service which was local and familiar to them. Arrangements for this were made through negotiations between the researcher and thee relevant expert service providers. Service providers also offered to provide support to the women, if they required it, as a consequence of being re-traumatised by the interview. Only one of the interviews was conducted in a public place (bar/restaurant) as it was convenient for the participant. The possible problems of discussing such a private and sensitive topic in such a public place were noted but the participant was not concerned. In the event, no problems were encountered. The only problem related to the transcription of the interview which was occasionally difficult due to background noise.

All interviews were between 60-120 minutes in duration. However breaks were incorporated into the interview time for different reasons including because the participant requested some time to regain her emotional composure after recollecting traumatic experiences, they need a comfort break or because they were needed to provide assistance to someone else. For instance, one of the women described herself as a full-time carer to her eighty year old mother who had Alzheimer's and thus needed to interrupt the interview when her mother needed personal assistance. 


\section{Research Findings}

Drawing on the data from the six selected case studies, this section of the paper will present the disabled women's reflections in relation to the different types of violence they encountered at different points in their lives including impairment specific violence, their experiences of the formal and informal support mechanisms they drew upon at these times, and their own aspirations for the protection of disabled women/ girls who have survived violence and the prevention of such violence in the future. In this regard, three key themes will be discussed here: 'Experiences of violence over life', 'Access to support' and 'Future Aspirations' to exemplify the reality for disabled women who are survivors of violence.

\section{Theme 1: Experiences of violence over life}

According to the disabled women in the sample the situation of violence encompassed several things including Physical and sexual violence, emotional abuse or economic coercion. Physical violence was seen in terms of being hit and beaten, psychological or emotional violence involved being verbally attacked, physically isolated from others, being conditioned to feel worthless by the perpetrator saying and doing things to purposely lower the woman's self esteem and confidence.

Women gave examples of the types of violence they encountered at different points in their life course, from childhood to adulthood. For example Barb recalls being violated at different stages of her life, from the age of about eight:

\footnotetext{
I think at different stages through my life there's been things that have happened. Sort of as a child I remember being, I suppose you could call sexual assaults, when I was about eight years old. Then in my marriage, I was married at 17, my husband was physically violent to me maybe about 4 times. And then the longer relationship that I had later on was everything: physical violence, sexual violence, emotionally and I tend to see a sort of mental torture that's quite different, it's a sort of extreme of the emotional abuse. It was really really bad, to the point where it was absolute mental torture. (Barbara)
}

Samantha reflects on the violence she was subjected to over her life by different male perpetrators, starting in childhood by her brothers, who beat her. At the age of nineteen/twenty she was forced, by her brothers, to marry a much older man who also abused her:

in those days we couldn't say nothing to our parents. My mum died when I was two and my dad died when I was sixteen. My brothers used to beat us up a lot; maybe because they wanted to be - yes, in other words that's right - they wanted to be in control. They were controlling us, they were controlling 
all the sisters. All my three brothers... They arranged or forced my marriage because my dad had passed away when I was sixteen. I was twenty at the time and he was about forty; or he could have been sixty. You know he never told me his age! And for the sake of me starting to talk to my sisters and my brothers I got married but I stayed in India for ages; eight months. They wouldn't let me - my husband wouldn't let me come back to England. I tried to commit suicide a couple of times and they [the husband's family] just got fed up and sent me back to England.

Lois also recalls experiencing abuse by a male member of her family. Her experience was longitudinal, starting during childhood and ending in early adulthood. Like Sam she tried to eliminate the memories of the violence, and the psychological scars it caused. However she did this through alcohol as opposed to attempted suicide:

when I was about six-seven and thirteen I experience abuse from an extended family member... when I was about 14 or 15 , I was raped, but maybe one or two friends knew about that but no one really knew it didn't come out in full until I was 18 or $19 \ldots$ I used to have to drink a pint glass of wine before I go to sleep and that was usually in combination with a lot of my medication as well, so that would be how I would get to sleep without worrying. I used to not being able to handle being in any sort of silence and cope with it because of my mind would take over and get trapped and think really negative.

Some of the women experienced impairment-specific abuse, a type of violence not experienced by non-disabled women. This type of abuse took place out of sight. It was related to isolation, control and manipulation. For example, Adele recollects how she experienced abuse for a good part of a decade, starting when she was a young teenager. The perpetrator, who was in their 20s at the time, was Adele's carer and sexual partner. Adele believes that the perpetrator definitely took advantage of the fact she had an impairment to abuse her. However, at the time she did not recognize it as abuse:

He would tell friends that I was poorly when he'd zonked me out. If you've had very strong painkillers, you're very dozey; so he would purposefully give me the strongest painkillers when my friends were coming, and they couldn't come then obviously because I was asleep. He would cancel care shifts, he would then say that I'd cancelled them, because again when you've had them tablets you're not good at remembering anything - even what your name is... he'd give you so much that you didn't know what you'd done...I just woke up and I thought I might have smacked myself in the eye. Now luckily I'm not with him anymore. But, like now, my mates know if I've smacked myself in the eye. Before now, I didn't really know what he did to me which is probably the worst thing actually.

Alison, another participant, was victim of physical, psychological and financial abuse. She identified some of the violence she experienced by her three husbands as related to her being disabled. She believes all of them saw her as an easy target and easy to control: 
My first husband saw me as a meal ticket because of my impairment... My husband, at the time, isolated me from my peers so I felt so alone...It was about control; if you're abusive it doesn't matter where the abuse leads it's always about control. They've got a manual, they've got the same book; you can laugh but they have

\section{Theme 2: Access to support}

The women mentioned different kinds of support they tried to access at different times. This was both formal and informal, resulting in positive and negative outcomes. There were several examples of women experiencing barriers to accessing support over their lives. These barriers were caused by different individuals and structures. For instance, both Barb and Lois remembered how their own families avoided formally reporting the abuse they experienced for fear of the scandal it may create:

\footnotetext{
I think the thing that hurts me the most was probably my parent's reaction - my mum particularly, I think they must have been thinking do they phone the police, if they do, you know, it' $\mathrm{d}$ be a big scandal; it would be in the paper - all this kind of thing. A sort of shameful situation and I remember hearing my mum saying that "she's young, she'll just forget about it if we don't mention it". And it was just swept under the carpet. (Barb)
}

Lois was sexually abused by her cousin from when she was age seven to thirteen. Although it was made known to her immediate and extended family, her family was frightened of the scandal it may cause within their community and thus preferred not to formally report it to the police at the time. When Lois was 18 and went to the police herself, she felt she was not fully believed because her parents "were in denial" and thus "skipped over what was important" in the reports they gave.

Alison tried various avenues of formal support for the domestic abuse she was subjected to by her husbands. However she faced disabling attitudinal barriers by support services which resulted in her children being removed from her for a while:

I did try but they just didn't grasp it [...] and when I did turn to anyone for help it went all wrong so in the end I nearly lost the kids, I did lose the kids for at least a while... Me: I was branded as the worst mum in the world

Despite the fact Alison was experiencing on-going violence from partners, she could not access formal or informal support. She requested to be relocated for her and her children's safety, but there were no services that offered support for her as both a disabled woman and mother : 
all I needed was a helping hand to say: "here you are; here's a place, here's some money, and with your kids - we're going to give you some support. We'll find you a job, or a job interview even, we'll start you on your way and then it's up to you. That's all I needed

Barb also had to put up with years of severe abuse from her second husband. This started in 1988:

I'm don't know how I got into this situation but it turned out to be sixteen years long and it ws just very very bad; violence, sexually violence; rape, hundreds of times literally. Just completely broke me down and I just think that people understand that there's abuse and there's just absolute torture in it's extreme form and that's where the relationship went.

Barb's husband had isolated her from her family and friends for years, since the late 1980s. She knows that neighbours and the police were aware of the high level of domestic abuse she was being subjected to, but they were waiting until she cried for help. They did not seem to understand that years of abuse and intrinsic fear for herself and her children meant she lacked the confidence to make a formal complaint. This unfortunately meant the police were not prepared to charge the perpetrator and he was free to continue to victimise Barb again and again:

... I don't think I told anyone but lots of people knew because there was a lot of police involvement and things. I was quite seriously injured a number of times and hospitalised a number of times... I think in some ways that the attitude of the police could also be a huge problem because in some ways I felt that they looked on me as being just as bad because I wouldn't do something about it; you know sort of "how do you expect us to help you if you wont help yourself?" Yes, that's fine but I couldn't help myself. I don't think they were able to sort of understand this prisoner of war camp that I had going on. You know I remember at the very end when I was finally leaving the police put it too me that "you know we've tried to help you so many times." At this point I was actually going, I'd left the house and I was asking them to help me and the inspector was like "Why should I put my officers at risk so you can go home and play happy families tomorrow?" ...

Lois also wanted assistance from the police but felt her drinking and sexually promiscuous behaviour, adopted as mechanisms over the years to cope with the scars of abuse, would be used as negative evidence and reduce the likelihood they would help her:

I felt I couldn't go to the police because I felt I'd be scrutinized and I felt that everything that I'd done ever since would be used as evidence against me and because I felt all is based on your character and instead of being believed and because of the way I behaved in the time since what has happened to me, I felt like people would say it's my fault or I brought it on myself or that I have to go to court and 
explain things... I thought it would be very easy for anyone to say well of course with how much you have drunk at the time

In Barb's case, however, eventually the police did take positive action and persuaded her to leave the abuse situation:

by 2004 the police weren't just going to go away ,they were coming in. And you know the police then did press charges against him, regardless of what I said, based on what they could see. So I think whether there'd been changes in legislation during that time or the approach that the police would take; the sort of guidelines that they worked within

This could have been prompted by several things, including the approach taken by successive U.K. governments to tackle domestic violence by policy development (such as the Sexual Offences Act, 2003, and Domestic Violence, Crime and Victims Act 2004), and Barb's own agency and self-confidence to negotiate her own escape routes. She believes that becoming employedin a support service for people with her impairment provided her with opportunities to learn about similar cases and support mechanisms. She also befriended someone from work with whom she confided:

In January my friend and her husband drove me to my kids school and picked them up and we ran. My three youngest children we got from school and we went into refuge with Women's Aid. And that was the last time we ever went back there

In another case, Shirley reveals how she was continuously physically abused, by her father when she was growing up in New York City in the 1970s. She believes that part of the problem was children did not have many rights, as they do today. This was prior to the Children's Act and when child abuse was a private affair not a public matter:

When I was 14, I called something called Child Protection Services, in New York City in America and I was told I would be entitled to Family Counselling. I said that I thought my father was a danger to me and that he was excessively violent, and that I was in fear of something horrible happening to me like him putting me in hospital. And I was still pretty much fobbed off, and it was the family counsellor who said that until he did something quite nasty that would put me in hospital they could not do anything.

Even where her scars were obvious, professionals failed to believe Shirley was being abused, and thought she was the cause:

they (hospital staff) thought I was a heroin addict 'cause I was so thin and I had needle scratches because I was having medication and I was also having convulsions and with the convulsions they 
made assumptions and thought that I was a heroin addict and they treated me like a piece of dirt .... I collapsed on the floor and I was there for an hour and I then crawled back to my room and then I lost consciousness and was in a comma and they had to give me an adrenalin shot and I still have the scar.

On a more positive note, both Adele and Samantha discovered a support service in their home city that specialised in providing support to disabled women. It was run by a disabled woman, herself a survivor of domestic violence. The two women believed that, joining the service and meeting other disabled women who had experienced what they had caused a turning point for both of them. It provided them with a means to regain their confidence enough to be able to stop what was happening to them. For instance, after being in an abusive relationship for 10 years, Adele decided it was time to get out. She speaks of how meeting the manager of the disabled women's support service prompted her to do so:

\footnotetext{
I was 23 when I started trying to get out of it but it takes a lot of time. I think to get to the point where you can't stand it anymore. You try to change it but then it doesn't change and you have to get out... she (the manager) was talking about smear tests and stuff like that. Then afterwards she started talking about this: domestic violence towards women, and it just sort of clicked into place that I've got to go, he's got to go. Even if I had to go back to my parents he's got to go.
}

\title{
Theme 3: Future Aspirations
}

At the end of each life history interview the women were asked 'If you had a magic wand what would you wish for to protect disabled women and girls from violence'. Several of the women emphasized the importance of education and training to promote an awareness of the consequences of violence for both the abused and the abuser. Also there was a perception that through disability awareness members of society could learn acceptable and unacceptable treatment for disabled people, and how it should not be different to what is acceptable and unacceptable for non-disabled people/children.

\begin{abstract}
Alison suggests that disabled girls should be given sex education in schools, be these segregated or mainstream. This should include knowledge about the difference between right and wrong sexual behaviour, information about their entitlement to resist anything they do not like no matter who the perpetrator is, and advise about how to report any wrong behaviour.
\end{abstract}

The last word is from Barb, again in relation to education and ensuring women can access the right information: 
I know that nowadays the health visitor will talk to new mums about postnatal depression. Well maybe the subject of violence in a relationship could be covered at that stage; just really getting the information to women. If it hadn't been for my work I wouldn't have known that there were people out there that could help and when it came to it for me the obvious people like the police didn't give me that help initially; I had to do it for myself. Yes, educating people and getting the information to people would help

\section{Conclusion}

This paper brings the voices of disabled women to the forefront of debates on violence against women and on disability, two areas of research and policy which have marginalised the experiences of disabled women. It discusses the reality that disabled women are significantly more likely to experience violence compared to their non-disabled contemporaries, at the hands of different perpetrators, including paid and unpaid carers, and in various ways including those specific to their impairment. Drawing on preliminary evidence from life history interviews with disabled women based in the U.K., the paper suggests how disabled women and girls experience particular types of violence specific to their impairment which is often not recognised as violence (by professionals or even the women themselves) but rather part of the everyday life of a disabled person. Further the paper highlights how disabled women are at the intersection of gender and disability bias and, as a result, likely to encounter a range of barriers to support. Such barriers are influenced by a number of factors including: historical perceptions of disabled women as asexual and incompetent as sexual partners or mothers, being dependent on perpetrators for personal care, physical inaccessibility of specialist support systems and the disbelief women face when reporting their experiences to professionals. However, regardless of these barriers, the disabled women, introduced in this paper, are all survivors because they drew on other support mechanisms, including their own agency, and support from, and identification with, other disabled women.

The article explored concepts of empathy and identification, highlighting how personal ontological research resources have not only become recognized as valid sources of scholarly knowledge and also as a means to enable respondents to share experiences with an empathic other (Shah, 2006; Riessman, 1994). As Karl (1995) observes, a sense of empowerment comes from being respected and recognized as equal citizens with a contribution to make.

Facilitating disabled women to speak out for themselves about their experiences of violence and support over the lifecourse can contribute to the development of future policies and 
1

2

3

4

5

6

7

8

9

10

11

12

13

14

15

16

17

18

19

20

21

22

23

24

25

26

27

28

29

30

31

32

33

34

35

36

37

38

39

40

41

42

43

44

45

46

47

48

49

50

51

52

53

54

55

56

57

58

59

60 practices in educational institutions and specialist support services. Learning from insider perspectives are crucial to develop tailored mechanisms to reduce the prevalence of violence against disabled women and girls in the future.

\section{Acknowledgements}

The authors would like to thank the disabled women who participated in the project on which this paper is based.

\section{Funder}

The work was supported by the European Commission [grant number: JUST/2011-2012] 


\section{References}

Adoption and Children Act (2002). (c23) London: the Stationary Office

Atkinson, R. (1998). The life story interview. London: Sage.

Balderston, S. (2014). Victimised again? Intersectionality and Injustice in disabled women's lives after hate crime and rape. Gendered Violence: Macro and Micro Settings. Advances in Gender Research, 18, 17-51.

Begum, N. (1992). Disabled women and the feminist agenda. In H. Hinds, A. Phoenix, and J. Stacey. (Eds.) Working out: New directions for women's studies (61-73). London: Falmer.

Barron, K. (2010). Bumpy road to womenhood. Disability and Society, 12, 2, 223-240.

Bashall, R. and Ellis, B. (2012) Nothing About Us Without Us: Policy and Practice. In Thiara, R., Hague, G., Bashall R., Ellis, B. and Mullender, A. (Eds.) Disabled Women and Domestic Violence: Responding to the Experiences of Survivors (106-136). London, Jessica Kingsley Publishers.

Belsky, J. (1980). Child maltreatment: An ecological integration. American Psychologist, 35, 4, 320-335.

Bertaux, D. (1981). From the life-history approach to the transformation of sociological practice. In Bertaux, D. (Ed.). Biography and Society: The life history approach in social sciences (29-45). London: Sage.

Booth, T. and Booth, W (1997). Making connections: A narrative study of adult children of parents with learning difficulties. In Barnes, C. and Mercer, G. (Eds.) Doing Disability Research (123-140). Leeds: Leeds University Press.

Booth, T. and Booth, W (1994). Parenting under pressure: mothers and fathers with learning difficulties. Buckingham: Open University Press

Bondi, L. (2003). Empathy and Identification: Conceptual Resources for Feminist Fieldwork. ACME: An International E-Journal for Critical Geographies, 2, 1, 64-76.

Campling, J. (1981). Images of Ourselves. London: Routledge \& Kegan Paul.

Cockram, J. (2003). Silent Voices: Women with Disabilities and Family and Domestic Violence. Nedlands, WA: People with Disabilities (WA) Inc.

Curry, M. A., Hassouneh-Phillips, D., \& Johnston-Silverberg, A. J. (2001). Abuse of women with disabilities: An ecological model and review. Violence Against Women, 7, 60-79.

Disability Discrimination Act 2005. (c.13). London: The Stationery Office

Disch, E. (2001) Research as clinical practice: creating a positive research experience for survivors of sexual abuse by professionals. Sociological Practice. : A Journal of Clinical and Applied Sociology, 3, 3, 221-239. 
Domestic Violence, Crime and Victims Act (2004). (c.28). London: The Stationary Office http://www.legislation.gov.uk/ukpga/2004/28/contents [26.3.13]

Equality Act 2010 Section 193 http://www.legislation.gov.uk/ukpga/2010/15/section/193 [17.4.13]

European Parliament resolution on the situation of people with disabilities in the enlarged European Union: the European Action Plan 2006-2007. (2006-2007 (INI))

Family Law Act (1996). (c.27). London: The Stationary Office

Finkelstein, V. (2001). The social model of disability repossessed. Retrieved January 2007, from http://www.leeds.ac.uk/disabilitystudies/archiveuk/finkelstein/soc\%20mod\%20repossessed.pdf

First international treaty to afford disabled people human rights: http://www.un.org/disabilities/convention/conventionfull.shtml

Forced Marriage (Civil Protection) Act 2007 http://www.legislation.gov.uk/ukpga/2007/20/contents [21.3.13]

Forced Marriage. (Protection and Jurisdiction) (Scotland) Act 2011 http://www.legislation.gov.uk/asp/2011/15/contents/enacted [26.3.13]

French, S. and Swain, J. (2006). Telling stories for a politics of hope, Disability and Society, $12,1,21-36$.

Hague, G. , Thiara, R.K. and Mullender, A. (2011). Disabled women and domestic violence: Making the links, a national UK study. Psychiatry, Psychology and Law, 18,1, 117.

Higgins, M. and Swain, J. (2010). Disability and child sexual abuse: Lessons from Survivors Narratives for Effective Protection, Prevention and Treatment. London: Jessica Kingsley.

Homelessness Act (2002). (c.7). London: The Stationary Office

Housing Act (1996). (c.52). London: The Stationary Office

Jennings, C. (2003). Violence and women with a disability break down the barriers. Available at www.wwda.org.au/jennings1.pdf, accessed on $8^{\text {th }}$ April 2014.

Karl, M. (1995). Women and Empowerment: Participation and Decision Making. New Jersey: Zed Books.

Kelly, L., Regan, L. and Burton, S. (1991). An Exploratory Study of the Prevalence of Sexual Abuse in a Sample of 16-21 Year Olds. Child Abuse Studies Unit. London: PNL. 
Kennedy, M. (1996). Sexual abuse and disabled children. In Morris, J. (Ed.) Encounters with Strangers. Feminism and Disability (116-134). London : The Women's Press Ltd.

Leicester, M. (1999). Disability Voice - towards an enabling education. London, Philadelphia: Jessica Kinsley Publishers.

Martin, S. L., Ray, N., a Sotres-Alvarez, D., Kupper, L.L., Moracco, K.E., Dickens, P.A., Scandlin, D. and Gizlice, Z. (2006). Physical and Sexual Assault of Women with Disabilities. Violence Against Women, 12, 823-838.

Ministry of Justice http://www.justice.gov.uk/ [26.3.13]

Morris, J. (1996). (Ed.) Encounters with Strangers: Feminism and Disability. London: The Women's Press Ltd.

Moser, C. A. (1958). Survey Methods in Social Investigation. London: Heinemann.

Nosek, M., C. Howland, and R. Hughes. (2001). The investigation of abuse and women with disabilities: Going beyond assumptions. Violence Against Women 7, 4, 477-499.

Oakley, A. (1981). Interviewing women: A contradiction in terms. In H. Roberts (Ed.). Doing feminist research (30-61). London: Routledge.

Priestley, M. (2003). Disability: A life course approach. Cambridge: Polity Press.

Protection from Harassment Act 1997 http://www.legislation.gov.uk/ukpga/1997/40/contents [4.4.13]

Protection of Freedoms Act 2012

http://www.legislation.gov.uk/ukpga/2012/9/contents/enacted [29.4.12]

Riessman, C. K. (1994c). Subjectivity Matters: The Positioned Investigator. In Riessman C.K. (Ed.) Qualitative Studies in Social Work Research (133-138). London: Sage.

Saxton, M., Curry, M.A., Powers, L.E., Maley, S., Eckels, K. and Gross, J. (2001). 'Bring my scooter so I can leave you': A study of disabled women handling abuse by personal assistance providers. Violence Against Women, 7 ,4, 393-417.

Schröttle, M. and Glammeier, S. (2013). Intimate Partner Violence Against Disabled Women as a Part of Widespread Victimization and Discrimination over the Lifetime: Evidence from a German Representative Study. International Journal of Conflict \& Violence, 7, 2, 233-248.

Sexual Offences Act 2003 http://www.legislation.gov.uk/ukpga/2003/42/contents [26.3.13]

Shah, S. (2006). Sharing the same world: The Researcher and the Researched. Qualitative Research,6, 2, 207-220. London: Sage.

Shah S., Priestley M. (2011). Disability and Social Change: Private Lives and Public Policies. Bristol: Policy Press. 
Shakespeare, T. (2014). Disability Rights and Wrongs Revisited. $2^{\text {nd }}$ ed. Abingdon: Routledge.

Shakespeare, T., Gillespie-Sells, K. and Davies D. (1996). The Sexual politics of Disability: Untold Stories. London: Cassell.

Sobsey, D., Randall, W. and Parrila R.K. (1997). Gender differences in abused children with and without disabilities. Child Abuse and Neglect, 21, 8, 707-720.

Sobsey, D., and T. Doe. (1991). Patterns of sexual abuse and assault. Sexuality and Disability, 9, 3, 243-59.

Stanley, L. and Wise, S. (1993). Breaking Out Again: Feminist Ontology and Epistemology. London: Routledge.

Sullivan, P. and and Knutson, J. (2000). Maltreatment and disabilities: a population based epidemiological study. Child Abuse and Neglect, 24, 10, 1257-1273.

Thiara, R. K., Hague G., Bashall R., Ellis B., Mullender, A. (2012). Disabled Women and Domestic Violence: Responding to Experiences of Survivors. London: Jessica Kingsley Publishers.

Thomas, C. (1999). Female forms: Experiencing and understanding disability. Buckingham: Open University Press.

United Nations Convention on the Elimination of all Forms of discrimination Against Women Seventh Periodic

Reports of States Parties: United Kingdom of Great Britain and Northern Ireland (2013) http://daccess-ddsny. un.org/doc/UNDOC/GEN/N11/648/56/PDF/N1164856.pdf?OpenElement [accessed $4^{\text {th }}$ April 2014]

UN (2006) Convention on Rights of Persons with Disabilities. Available at: http://www.un.org/disabilities/default.asp?navid=12\&pid=150 (accessed $21^{\text {st }}$ April 2014)

UN Convention on the Rights of a Child (1992)

https://www.gov.uk/government/policies/creating-a-fairer-and-more-equalsociety/supporting-pages/the-united-nations-convention-on-the-rights-of-the-child-uncrc

Westcott, H. and Cross, M. (1996). This far and no further: Tending the abuse of disabled children. Birmingham: Venture Press.

Womendez, C. and Schneiderman, K. (1991). Escaping from abuse: Unique experiences for Women with Disabilities. Sexuality and Disability, 9, 3, 273-280.

Women's Aid (2007). What is domestic violence? Available at www.womensaid.org.uk/domestic-violencearticles.asp? section $=00010001002200410001 \&$ itemid $=1272 \&$ itemTitle $=$ What + is + domestic + violence Accessed $28^{\text {th }}$ March 2014. 
Women's Aid Protection under Criminal Law (2008)

http://www.womensaid.org.uk/domestic-violence-

articles.asp? itemid $=1401 \&$ itemTitle $=$ Protection + under + criminal + law\&section $=00010001002$

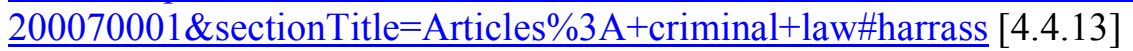

